
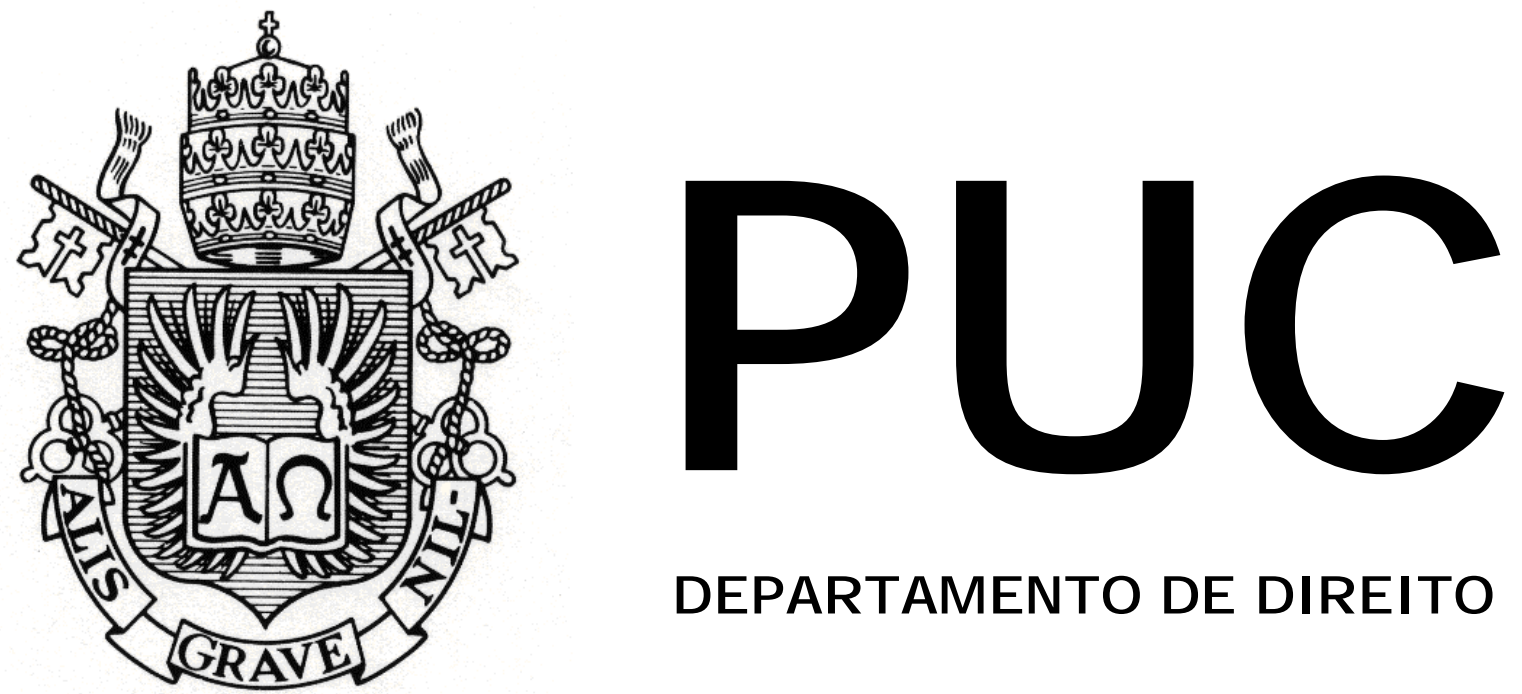

DEPARTAMENTO DE DIREITO

\title{
RELEGITIMANDO O ILEGITIMÁVEL: DIREITO PENAL, SIMBOLISMO E O RESSURGIR DO PUNITIVISMO
}

por

EDUARDO AUGUSTO AIRES CAVALCANTE

ORIENTADORA: VICTORIA-AMÁLIA DE SULOCKI 2011.1

PONTIFÍCIA UNIVERSIDADE CATÓLICA DO RIO DE JANEIRO RUA MARQUÊS DE SÃO VICENTE, 225 - CEP 22453-900 RIO DE JANEIRO - BRASIL 


\title{
RELEGITIMANDO O ILEGITIMÁVEL: DIREITO PENAL, SIMBOLISMO E O RESSURGIR DO PUNITIVISMO
}

\author{
por \\ EDUARDO AUGUSTO AIRES CAVALCANTE
}

Monografia apresentada ao Departamento de Direito da Pontifícia Universidade Católica do Rio de Janeiro (PUC-Rio) como requisito parcial para a obtenção do Título de Bacharel em Direito.

Orientadora: Victoria-Amália de Sulocki. 
"Já é hora de romper com os enganosos discursos legitimadores do sistema penal e construir - ou reconstruir - pensamentos $e$ práticas libertários e igualitários, fundados na generosidade, na fraternidade, na honestidade, na tolerância e no desapego verdadeiramente revolucionários”.

(Maria Lúcia Karam). 
Dedico este trabalho às mulheres da minha vida: avó, mãe, irmã e namorada, sem o seu apoio o caminho teria sido ainda mais tortuoso do que já fora. 


\section{Resumo}

O presente trabalho observou legislação, jurisprudência, doutrina brasileira e estrangeira com a finalidade de desvendar a problemática da concessão de legitimidade às manifestações do Estado brasileiro no âmbito do Direito Penal, marcada, nos últimos vinte anos, por um processo relegitimador expansionista. Com o intuito de contextualizarmos o tema proposto, abordamos os conflitantes paradigmas de legitimidade, construído pela teoria jurídica da pena e os fins utilitários que àquela credita, e de legitimação, desconstruído pela crítica criminológica da pena e as funções reais que àquela confere, para, assim, lançar uma luz tênue sobre os fenômenos do Direito Penal simbólico e do ressurgir do punitivismo, caracterizadores da demanda relegitimadora ora sofrida.

Palavras Chave: Teoria Jurídica da Pena; Criminologia Crítica; Direito Penal simbólico; Ressurgir do Punitivismo. 


\section{Sumário}

INTRODUÇÃ

Capítulo 1 - ObJetivos declarados ou manifestos: Direito Penal e EXCLUSIVA PROTEÇÃO DE BENS JURÍDICOS .................................................................. 10

1.1 - TEORIA JURÍDICA DA PENA E CONSTRUÇÃO DA LEGITIMIDADE: OS FINS

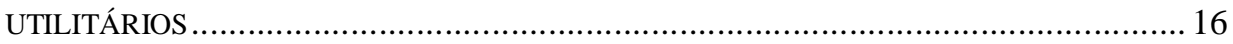

1.1.1 - TEORIAS ABOLICIONISTAS: MENÇÃO NECESSÁRIA ……..................... 18

1.1 .2 - TEORIAS ABSOLUTAS OU RETRIBUTIVAS …..................................... 20

1.1.3 - TEORIAS RELATIVAS, UTILITÁRIAS OU PREVENTIVAS ......................... 23

1.1.3.1 - DO UTILITARISMO MEDIANTE PREVENÇÃO ESPECIAL ..............24

1.1.3.2 - DO UTILITARISMO MEDIANTE PREVENÇÃO GERAL …...............26

1.1.4 - TEORIAS UTILITÁRIAS MISTAS OU UNIFICADORAS: A “POLÍTICA

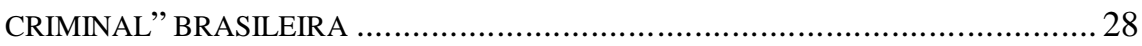

CAPÍTUlo 2 - OBJetivos Reais OU latentes: DiReito PENAL, CONTROLE SOCIAL

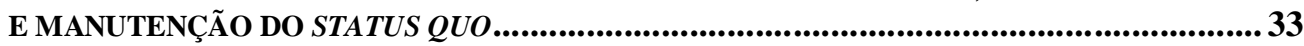

2.1 - MODERNISMO, INSTITUCIONALIZAÇÃO DO CASTIGO E O PARADIGMA DE

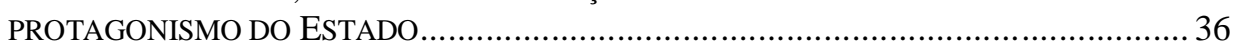

2.2 - DUAS CRÍTICAS CRIMINOLÓGICAS, UMA DESCONSTRUÇÃO DA LEGITIMIDADE:

DESCORTINANDO A LEGITIMAÇÃO COM O ESTUDO DAS FUNÇÕES DA PENA............... 41

\section{CAPÍTULO 3 - DEMANDA RELEGITIMADORA E MOVIMENTOS DE EXPANSIONISMO}

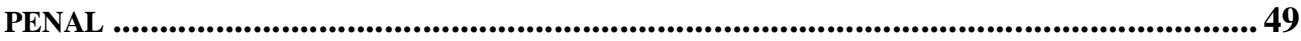

3.1 - DIREITO PENAL: SIMBÓLICO …………….............................................52

3.2 - O RESSURGIR DO PUNITIVISMO ATRAVÉS DA “ESQUERDA PUNITIVA”.............. 58

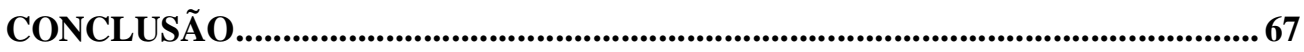

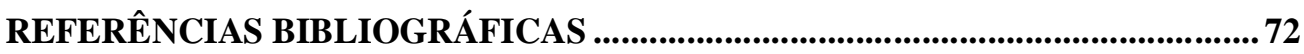




\section{Introdução}

A prática forense atual nos faz crer na singularidade da dicotomia "garantismo versus legalismo", aquela em que os autoproclamados "garantistas" e os ditos "reacionários" se digladiam, em síntese, pela limitação ou pela extensão da punição enquanto consequência do Direito Penal. Seja pela defesa do cidadão ante a arbitrariedade estatal ou pela defesa da sociedade ante ao que seria uma criminalidade galopante, ambos possuem sedutores argumentos, sendo impróprio que aqui se defina qual pólo, a despeito das suas ótimas, porém subjetivas intenções, deva ser melhor aceito.

É, todavia, da natureza das ciências jurídicas que haja diversos outros conflitos em termos de conceituação do Direito Penal. Uma delas é entre o que seria o discurso jurídico oficial, que, baseado em pressupostos ordinariamente jurídicos, porém, alinhados com a criminologia clássica, analisaria a ciência em questão através de uma ótica simplista, "manualesca", buscando os seus objetivos declarados ou manifestos, e entre criminologia crítica, que avaliaria de modo crítico os elementos de engano existentes na sociedade para, enfim, definir os objetivos reais ou latentes do Direito Penal. Tal celeuma, como não poderia deixar de ser, se desdobra em outra dicotomia referente à legitimidade/legitimação do exercício da pena na consecução daqueles objetivos, na qual, de um lado, a teoria jurídica da pena busca os fins declarados ou manifestos da sanção, e, de outro, a crítica criminológica da pena busca as suas funções reais ou latentes ${ }^{1}$.

Trata-se de uma análise feita segundo classificação utilizada pelo respeitadíssimo Juarez Cirino dos Santos $^{2}$ e pelos igualmente respeitados

\footnotetext{
${ }^{1}$ Sempre que falarmos em "fins" estaremos nos referindo ao que há de declarado ou manifesto no Direito Penal e na pena, ao passo que o termo "funções" sempre será utilizado para demonstrar o que há de real, latente ou dissimulado.

${ }^{2}$ SANTOS, Juarez Cirino dos. Direito Penal: Parte Geral. $4^{\mathrm{a}}$ ed. São José: Conceito Editorial, 2010. p. 04.
} 
Eugenio Raúl Zaffaroni e Nilo Batista ${ }^{3}$, apesar de suas bases, no que diz respeito à compreensão de aparência e dissimulação penal, irem a Alessandro Baratta ${ }^{4}$, Michel Foucault ${ }^{5}$, ao início do século XX com o russo Evgeny Bronislavovich Pachukanis ${ }^{6} \mathrm{e}$, até mesmo, às bases do marxismo. Justo mencionar, antes de mais nada, que todos os autores citados são adeptos da crítica criminológica da pena e que, s.m.j, não há uma defesa doutrinária do pensamento meramente jurídico, ele apenas representa o que há de oficial - rectius, oficioso - na literatura penal. As conclusões auferidas por ambas as abordagens diferem em grau exponencial.

O discurso jurídico oficial e sua teoria jurídica da pena compreendem como objetivo declarado ou manifesto do Direito Penal a exclusiva proteção de bens jurídicos ${ }^{7}$, a ser realizada através de uma "política criminal" fundada na retribuição equivalente ao mal e nos fins utilitários de prevenção especial e prevenção geral da pena, construção racionalmente paralela à lei vigente que deveria gerar uma diminuição da população compelida a cometer delitos. A teoria jurídica descreve, dessa forma, um paradigma de legitimidade do Direito Penal, de relação congruente entre programação normativo-penal e sua aplicação prática, cumpridora dos fins socialmente úteis fornecidos à pena.

A criminologia crítica e sua crítica criminológica da pena, a seu turno, veem no Direito Penal o objetivo latente de ser um instrumento de controle social institucionalizado destinado a, em maior ${ }^{8}$ ou menor ${ }^{9}$ escala,

\footnotetext{
3 ZAFFARONI, Eugenio Raúl; BATISTA, Nilo; ALAGIA, Alejandro; SLOKAR, Alejandro. Direito Penal Brasileiro: primeiro volume - Teoria do Direito Penal. $2^{\mathrm{a}}$ ed. Rio de Janeiro: Revan, 2003. p. 87.

${ }^{4}$ BARATTA, Alessandro. Criminología Crítica y Crítica del Derecho Penal: Introducción a la sociologia jurídico-penal. Tradução para o Espanhol de Álvaro Búster. Buenos Aires: Siglo Veintiuno, 2004.

${ }^{5}$ FOUCAULT, Michel. Vigiar e Punir. Tradução de Raquel Ramalhete. 32a ed. Petrópolis: Vozes, 2006.

${ }^{6}$ PACHUKANIS, Evgeny Bronislavovich. Teoria Geral do Direito e Marxismo. Tradução de Silvio Donizete Chagas. São Paulo: Acadêmica, 1988.

${ }^{7}$ SANTOS, Juarez Cirino dos. Direito Penal: Parte Geral. p. 05.

${ }^{8}$ Ibid. p. 09.
} 
manter as relações de hegemonia vigentes na sociedade. As classes dominantes valer-se-iam do monopólio legítimo da força nas mãos do Estado e dos fins utilitários de prevenção especial e, principalmente, prevenção geral em sua modalidade positiva, para exercer a função de transmissão cognitiva de uma mensagem de fidelidade ao Direito para os membros da sociedade, assegurando a manutenção do status quo ${ }^{10}$. A crítica criminológica defende, portanto, que a teoria jurídica da pena não descreve a legitimidade do Direito Penal, mas sim cria, mediante as teses utilitárias, um constante processo de legitimação (ou autolegitimação) pelo qual atribui aquela qualidade ${ }^{11}$.

Nossa intenção, no entanto, é expor a incoerência da prática legislativa brasileira nos últimos vinte anos, em que, apesar da comprovação empírica do descumprimento dos fins utilitários conferidos à pena, convivem contraditoriamente situações de desconfiança e reforço da sua exegese, proporção que pende para a segunda hipótese ${ }^{12}$. Se, por um lado, presenciamos algumas propostas político-criminais que assumem a pena como meio inidôneo à resolução de determinados conflitos e cogitam a minimização do seu exercício, por outro, experimentamos uma massiva demanda social relegitimadora de sua intervenção.

Assim, esboçaremos no primeiro capítulo uma análise do que há de manifesto e positivado em termos de justificação jurídico-penal, da exclusiva proteção de bens jurídicos à construção da legitimidade prestada pela teoria jurídica da pena, passando pelos fins utilitários que as sustentam.

\footnotetext{
${ }^{9}$ ZAFFARONI, Eugenio Raúl. Manual de Direito Penal Brasileiro. $2^{\text {a }}$ ed. São Paulo: Revista dos Tribunais, 1999. p. 67.

${ }^{10}$ SULOCKI, Victoria-Amália de. Segurança Pública e Democracia: Aspectos Constitucionais das Políticas Públicas de Segurança. Rio de Janeiro: Lumen Juris, 2007. p. 197.

${ }^{11}$ BARATTA, Alessandro. Criminología Crítica y Crítica del Derecho Penal: Introducción a la sociologia jurídico-penal. p. 178.

12 ANDRADE, Vera Regina Pereira. A Ilusão de Segurança Jurídica: Do controle da violência à violência do controle penal. $2^{\mathrm{a}}$ ed. Porto Alegre: Livraria do Advogado, 2003. pp. 293-297.
} 
No segundo capítulo, teceremos as considerações afeitas à criminologia crítica, que estuda o Direito Penal através do seu dissimulado objetivo de controle social dos dominados pelos dominantes e da potencialização deste processo ocorrida durante o modernismo, ocasião em que se edificara o Estado como detentor do monopólio da força. Desenvolveremos, ainda, a crítica criminológica da pena e a dissensão entre fins utilitários manifestos e funções latentes na consecução daquele controle social, desconstruindo a legitimidade descrita pela teoria jurídica da pena e caracterizando-a como mera legitimação.

Contextualizada a questão nos primeiros dois capítulos, estudaremos, no terceiro, a atual demanda relegitimadora do Direito Penal e do clamar social pela expansão do ius puniendi, gerados, fundamentalmente, pelos fenômenos do Direito Penal simbólico, enquanto inerência da ciência e gênero permissivo de legislações também simbólicas, e do ressurgir do punitivismo, o qual, no Brasil, nos parece representado pela chamada "esquerda punitiva".

Feitas essas considerações, passemos ao estudo do tema proposto. 


\section{Capítulo 1 - Objetivos declarados ou manifestos: Direito Penal e exclusiva proteção de bens jurídicos}

Poder-se-ia dedicar dezenas de obras àquela que é a primeira questão filosófica fundamental do Direito Penal: o que é o Direito Penal ${ }^{13}$ ? Assevere-se que ao aqui utilizarmos esta expressão estaremos, via de regra, tratando dos seus conceitos objetivo ${ }^{14}$ e legislativo ${ }^{15}$, frequentemente análogos, ignorando, assim, a celeuma sobre a denominação terminológica da ciência em penal ou criminal ${ }^{16}$.

Poucos foram os autores que lograram sucesso em responder de forma sintética e pedagógica a questão em comento. Franz Von Liszt definiu o Direito Penal como o "conjunto das prescrições emanadas do Estado, que ligam ao crime, como fato, a pena como consequência"17. Semelhante concepção conferiu-o Hans Welzel, segundo o qual o é "a parte do ordenamento jurídico que determina as ações de natureza criminal e as vincula com uma pena ou medida de segurança"18. De igual modo, Claus Roxin inicia o Tomo I de sua consagrada coleção dizendo que o Direito Penal se compõe "de todos los preceptos que regulam los presupuestos o consecuencias de una conducta conminada con una pena o con una medida de seguridad y correción" ${ }^{19}$. Eugenio Raúl Zaffaroni, por sua vez, sai com a seguinte frase ao confrontar-se com a questão em voga:

“(...) podemos dizer provisoriamente que o direito penal (legislação penal) é o conjunto de leis que traduzem normas que pretendem tutelar bens jurídicos, e que determinam o alcance de sua tutela, cuja violação se chama 'delito', e aspira

\footnotetext{
${ }^{13}$ ZAFFARONI, Eugenio Raúl. Manual de Direito Penal Brasileiro. p. 85.

${ }^{14}$ SOLER, Sebastian. Derecho Penal Argentino: Tomo I. Buenos Aires: Tipográfica Argentina, 1956. p. 21.

${ }^{15}$ ZAFFARONI, Eugenio Raúl. Manual de Direito Penal Brasileiro. p. 86.

${ }^{16}$ NORONHA, Magalhães. Direito Penal: Introdução à Parte Geral. 17 ${ }^{\mathrm{a}}$ ed. São Paulo: Saraiva, 1979. p. 11.

${ }^{17}$ LISZT, Franz Von. Tratado de Direito Penal Alemão: Tomo I. Tradução de José Higino. Campinas: Russel, 2003. p. 01.

${ }^{18}$ WELZEL, Hans. Direito Penal. Tradução de Afonso Celso Rezende. Campinas: Romana, 2003. p. 27.

${ }_{19}$ ROXIN, Claus. Derecho Penal: Parte General. Tradução para o Espanhol de Diego Pena. Madrid: Civitas, 1997. p. 41.
} 
que tenha como conseqüência uma coerção jurídica particularmente grave, que procura evitar o cometimento de novos delitos por parte do autor" ${ }^{20}$. (grifamos)

Nítido que todas as definições citadas constituem formas distintas, porém coerentes, de se falar a mesma coisa: o Direito Penal é uma súmula de enunciados e definições cogentes cuja violação desencadeia um juízo de valor e, posteriormente, uma sanção a ser aplicada ao transgressor ${ }^{21}$.

Nada obstante à lexicográfica superficialidade da frase acima, suas entrelinhas escondem aqueles que são considerados os três grandes fatos que compõem a nossa ciência ${ }^{22}$ : a tipificação, pelo Estado, dos atos tidos como criminosos; a aplicação ao eventual autor do juízo de valor oficial do Estado; e a execução, pelo Estado, de medida repressiva ao que venha a ser considerado culpado. Observe-se, aliás, a conveniência da pouco aconselhável reiteração do termo "Estado" na sequência naturalística tripartida acima; enquanto definidor, aplicador e executor, o Estado ${ }^{23}$ constitui hodiernamente a entidade coletiva, política e jurídica responsável por todos os faceri que envolvem o atuar penal.

Frente ao seu papel enquanto sujeito único da potestade penal e titular do poder de império $^{24}$, diz-se corresponder a um Direito Penal subjetivo, usualmente substituído pela expressão latina ius puniendi ${ }^{25}$, que

\footnotetext{
${ }^{20}$ ZAFFARONI, Eugenio Raúl. Manual de Direito Penal Brasileiro. p. 85.

${ }^{21} \mathrm{Na}$ mesma direção seguem as definições de alguns dos principais penalistas pátrios. Para Magalhães Noronha (NORONHA, Magalhães. Direito Penal: Introdução à Parte Geral. p. 12) é o “(...) conjunto de normas jurídicas que regulam o poder punitivo do Estado, tendo em vista os fatos de natureza criminal e as medidas aplicaveis a quem os pratica". Cezar Bitencourt (BITENCOURT, Cezar Roberto. Manual de Direito Penal: Parte Geral. $6^{a}$ ed. São Paulo: Saraiva, 2000. p. 02), por sua vez, o apresenta como “(...) um conjunto de normas jurídicas que tem por objeto a determinação de infrações de natureza penal e suas sanções correspondentes - penas e medidas de segurança".

${ }^{22}$ Trata-se de uma tripartição da ciência que é suficientemente abordada por Ferrajoli (FERRAJOLI, Luigi. Direito e Razão: Teoria do Garantismo Penal. Tradução por Ana Paula Zomer Sica, Fauzi Hassan Choukr, Juarez Tavares e Luiz Flávio Gomes. $2^{a}$ ed. São Paulo: Revista dos Tribunais, 2006. p. 245).

23 “(...) todas as sociedades políticas que, com autoriedade superior, fixaram as regras de convivência de seus membros”. DALLARI, Dalmo de Abreu. Elementos de Teoria Geral do Estado. $25^{\mathrm{a}}$ ed. São Paulo: Saraiva, 2006. p. 9.

${ }^{24}$ BITENCOURT, Cezar Roberto. Manual de Direito Penal: Parte Geral. p. 7.

${ }^{25}$ BALESTRA, Carlos Fontán. Tratado de Derecho Penal: Tomo I. $2^{\mathrm{a}}$ ed. Buenos Aires: AbeledoPerrot, 1953. p. 185.
} 
literalmente significa direito de punir. Esta faculdade deveria, sem embargo, ser limitada pelo Direito Penal objetivo, constituído pelos limites estabelecidos pela legislação penal e processual penal ${ }^{26}$, bem como pelo antagônico e, ao menos formalmente, prevalecente ius libertatis. Costumase dizer que a maior expressão do Direito Penal objetivo, enquanto autorrestrição ao direito de punir em um Estado Democrático de Direito, é do chamado princípio da legalidade, porque proíbe: a retroatividade como criminalização ou agravação da pena de fato anterior; o costume como fonte da lei penal; a analogia in man partem; e a indeterminação dos tipos e sanções penais ${ }^{27}$. De nada adiantaria, contudo, a existência de um princípio formal como esse se, materialmente, o Estado pudesse exercer o seu múnus ao bel-prazer, criando e aplicando leis com conteúdo duvidoso.

Não por acaso, portanto, que grifamos "normas que pretendem tutelar bens jurídicos" no bem lançado conceito de Zaffaroni; trata-se do seu elemento diferencial, componente que o torna sui generis aos outros. A exclusiva proteção de bens jurídicos ${ }^{28}$ ante uma possível ofensa é, em última instância, o principal objeto manifesto do Direito Penal ${ }^{29}$, intenção esta vinculada ao vigente princípio constitucional da lesividade ou ofensividade, que proíbe ao Estado a tipificação, aplicação e a execução de penas e medidas de segurança em casos de lesões irrelevantes contra bens jurídicos tutelados pela lei penal ${ }^{30}$, aplicando-se, portanto, às três fases da sequência jurídica tripartida anteriormente abordada. Em uma interpretação antagônica, tal postulado inspira o cerne do chamado princípio da insignificância, segundo o qual o Direito Penal não se presta à punição de lesões insignificantes aos bens protegidos ${ }^{31}$.

\footnotetext{
${ }^{26}$ BALESTRA, Carlos Fontán. Tratado de Derecho Penal: Tomo I. p. 185.

${ }^{27}$ SANTOS, Juarez Cirino dos. Direito Penal: Parte Geral. p. 20.

${ }^{28}$ MIR PUIG, Santiago. El Derecho Penal en el Estado Social y Democrático. Barcelona: Ariel, 1994. p. 159.

${ }^{29}$ SANTOS, Juarez Cirino dos. Direito Penal: Parte Geral. pp. 04-05.

${ }^{30}$ Ibid. p. 26.

${ }^{31}$ Ibid. p. 26.
} 
As ideias que se tem da expressão "bem jurídico" são tão numerosas quanto aquelas do próprio Direito Penal, consistindo a sua base comum na proteção do que seriam os interesses humanos mais elementares por via da repressão oficial. Apesar de ser ter sido precedida pelas criações conceituais de Birnbaum ${ }^{32}$ e Binding ${ }^{33}$, é de Von Liszt o conceito mais universalmente aceito:

"Bem é, pois, o interesse juridicamente protegido. Todos os bens jurídicos são interesses humanos, ou do indivíduo ou da coletividade. É a vida, e não o direito, que produz o interesse, mas só a proteção jurídica converte o interesse em bem jurídico. (...) Os interesses, porém, surgem das relações dos indivíduos entre si e dos indivíduos para com o Estado e a sociedade ou vice-versa. Onde há vida há força que tende a manifestar-se, afeiçoar-se e desenvolver-se livremente. Em pontos inúmeros, os círculos da vontade humana tocam-se e cruzam-se, colidem as esferas em que os homens exercem a sua ação. A essas relações corresponde o interesse de cada um à ação ou inação de outrem, quando a ação ou inação tem importância para a própria eficiência”, ${ }^{34}$.

Os interesses, enquanto prováveis bens jurídicos, são fruto das relações sociais dos cidadãos e entre esses e a autoridade superior regulamentadora, relações estas extremamente dinâmicas e variáveis de acordo com a evolução do pensamento humano. Cite-se, por exemplo, o ius primae noctis, segundo o qual o líder de uma coletividade possuía o direito de "exercer com toda mulher que se casava a prerrogativa da primeira noite" ${ }^{, 35}$; era um interesse característico de tempos medievais e que fora abolido ainda no século XV. Oriunda dessas constantes mutações sociais e culturais a dificuldade de se oferecer um catálogo fechado, numerus clausus dos bens suscetíveis à tutela penal ${ }^{36}$, empecilho que se alastra ao restante das ciências afetas ao Direito.

A transformação dos interesses sociais em bens jurídicos passa também pelo que seria a vontade do Estado em concebê-los como tal

\footnotetext{
${ }^{32}$ Ibid. p. 5.

${ }^{33}$ LISZT, Franz Von. Tratado de Direito Penal Alemão: Tomo I. p. 141.

${ }^{34}$ Ibid. pp. 139-140.

35 SOARES, Orlando. Causas da Criminalidade e Fatores Criminológicos. Rio de Janeiro: Científica, 1978. p. 25.

${ }^{36}$ GOMES, Luiz Flávio. Norma e Bem Jurídico no Direito Penal. São Paulo: Revista dos Tribunais, 2002. p. 54.
} 
através de sua função legislativa, que decorreria, ainda segundo Von Liszt $^{37}$, da legitimação a ele concebida pelo contrato social enquanto impedimento da guerra de todos contra todos. Não seria razoável, contudo, que este poder fosse absoluto, razão pela qual Roxin afirma que "la única restricción previamente dada para el legislador se encuentra em los princípios da la Constituición" ${ }^{38}$.

No Brasil, grande parte dos bens jurídicos sobrepesados no já ultrapassado Código Penal, como a vida, a honra e a administração pública, ${ }^{39}$ tiveram a sua exegese durante a antidemocrática Constituição do Estado Novo, outorgada por Getúlio Vargas em de 1937. Passados tenebrosos tempos desde então, a Constituição da República Federativa de 1988 veio a instituir formalmente o moderno Estado Democrático de Direito no caput do seu art. $1^{\mathrm{o}}{ }^{40}$, modelo de Estado em que se repudia - ou deveria repudiar - a utilização do Direito Penal como proteção da moral ou a ética, valores sociais ${ }^{41}$ e a religião ou obediência divina ${ }^{42}$.

Ainda por força da Constituição e do seu princípio da proporcionalidade ${ }^{43}$, diz-se que a proteção de bens jurídicos por via do

\footnotetext{
${ }^{37}$ LISZT, Franz Von. Tratado de Direito Penal Alemão: Tomo I. p. 141. A influência das idéias contratualistas e modernistas no Direito Penal será melhor abordada no item 2.1, infra.

${ }^{38}$ ROXIN, Claus. Derecho Penal: Parte General. p. 55.

${ }^{39}$ Título I, Capítulos I, V e XI, respectivamente.

40 “Art. 1 A República Federativa do Brasil, formada pela união indissolúvel dos Estados e Municípios e do Distrito Federal, constitui-se em Estado Democrático de Direito (...)”.

${ }^{41}$ A questão é controversa e confusa. Welzel (WELZEL, Hans. Direito Penal. pp. 27-28) acredita que é a missão do Direito Penal convolar os valores ético-sociais essenciais em bens jurídicos tutelados. Zaffaroni (ZAFFARONI, Eugenio Raúl. Manual de Direito Penal Brasileiro. pp. 97-98) entende que o Direito Penal é digno à proteção de valores éticos, desde que a "ética" se refira à pauta de condutas sociais constituídas pela sociedade e não à moral, enquanto consciência individual. Luiz Flávio Gomes (GOMES, Luiz Flávio. Norma e Bem Jurídico no Direito Penal. p. 46) compreende moral e ética no mesmo sentido, acrescentando valores culturais ao bojo de proteções ilegítimas. Hassemer (HASSEMER, Winfried. Derecho Penal Simbólico y Protección de Bienes Jurídicos. Tradução para o espanhol de Elena Larrauri. In: Vários autores. Pena y Estado. Santiago: Editorial Jurídica Conosur, 1995. p. 32) diz que a política criminal moderna entende que os atos que atentem contra a moral e os valores sociais devem excluir-se do catálogo de delitos.

${ }^{42}$ GOMES, Luiz Flávio. Norma e Bem Jurídico no Direito Penal. p. 46.

${ }^{43}$ ROXIN, Claus. Derecho Penal: Parte General. p. 65. Segundo Juarez Cirino (SANTOS, Juarez Cirino dos. Direito Penal: Parte Geral. p. 27) o princípio da proporcionalidade é constituído pelos "subprincípios" da adequação, necessidade e proporcionalidade em sentido estrito.
} 
Direito Penal possui natureza subsidiária e fragmentária ${ }^{44}$. É uma proteção subsidiária porque deve ser a última de todas as medidas protetoras que o Estado deve considerar, somente podendo dela se valer caso não existam outros meios aptos ${ }^{45}$. É, por outro lado, fragmentária porque não protege todos os bens tratados pela Constituição da República e, quando o faz, erige apenas parcialmente à tutela aqueles bens ${ }^{46}$. Tais conceitos aludem, respectivamente, aos modernos princípios da intervenção mínima ou ultima ratio e da fragmentariedade ${ }^{47}$.

Confira-se, apenas a guisa de remate, ementa de julgado da egrégia corte que aglutina os conceitos ora expendidos:

"EMENTA: RECURSO ORDINÁRIO EM HABEAS CORPUS. PENAL MILITAR. PROCESSUAL PENAL MILITAR. FURTO. INEXISTÊNCIA DE LESÃO A BEM JURIDICAMENTE PROTEGIDO. PRINCÍPIO DA INSIGNIFICÂNCIA. AUSÊNCIA DE JUSTA CAUSA PARA A PROPOSITURA DA AÇÃO PENAL MILITAR. 1. Os bens subtraídos pelo Paciente não resultaram em dano ou perigo concreto relevante, de modo a lesionar ou colocar em perigo o bem jurídico reclamado pelo princípio da ofensividade. Tal fato não tem importância relevante na seara penal, pois, apesar de haver lesão a bem juridicamente tutelado pela norma penal, incide, na espécie, o princípio da insignificância, que reduz o âmbito de proibição aparente da tipicidade legal e, por consequiência, torna atípico o fato denunciado. É manifesta a ausência de justa causa para a propositura da ação penal contra o ora Recorrente. Não há se subestimar a natureza subsidiária, fragmentária do Direito Penal, que só deve ser acionado quando os outros ramos do direito não sejam suficientes para a proteção dos bens jurídicos envolvidos. 2. Recurso provido" ${ }^{48}$.

Assim prevendo a Constituição e grande parte da doutrina jurídico-

penal em geral, razoável que a jurisprudência validasse o entendimento de que o principal objetivo do Direito Penal é a proteção subsidiária e fragmentária de bens jurídicos ante alguns dos atos que efetivamente produzam ofensas ou lesões. A frase acima baseia a espinha dorsal do

\footnotetext{
${ }^{44}$ SANTOS, Juarez Cirino dos. Direito Penal: Parte Geral. p. 5.

45 BARATTA, Alessandro. Principios de Derecho Penal Mínimo. In: BARATTA, Alessandro (Compilação in memoriam). Criminología y Sistema Penal. Buenos Aires: Editorial B. de F., 2004. p. 312.

${ }^{46}$ ROXIN, Claus. Derecho Penal: Parte General. p. 66.

${ }^{47}$ BITENCOURT, Cezar Roberto. Manual de Direito Penal: Parte Geral. pp. 11-12.

${ }^{48}$ STF, RHC 89624-RS, $1^{\text {a }}$ T., Rel. Ministra Carmen Lúcia. DJ 07.12.06.
} 
princípio da exclusiva proteção de bens jurídicos e de sua teoria ${ }^{49}$, que, em conjunto com os outros princípios também brevemente abordados (legalidade, ofensividade, insignificância, proporcionalidade, ultima ratio e fragmentariedade), constitui o núcleo essencial das esperanças de que delimite objetivamente e igualitariamente o ius puniendi estatal $^{50}$.

Enfim, relevante dizer que a concepção meramente jurídica dos objetivos do Direito Penal de fato possui claros méritos em, ao menos, tentar limitar a atuação do Estado ao imaginar o bem jurídico como critério de criminalização e como objeto de proteção, quando da aplicação e execução da pena. Pouco ou nada vale, contudo, que se diga que o Estado deve ser limitado por um parâmetro constitucional qualquer sem sequer tentar compreender de que forma e através de que efeitos buscará, com a pena, o cumprimento de tal objetivo. Trata-se de uma discussão afeita à teoria da pena.

\section{1 - Teoria jurídica da pena e construção da legitimidade: Os fins utilitários}

Há pouco afirmamos que o direito de punir é de titularidade exclusiva e soberana do Estado e que este deverá fixar normas de conduta protetoras de bens jurídicos relevantes à coletividade ${ }^{51}$, conclusões que remetem, respectivamente, às próprias definições de Direito Penal subjetivo e Direito Penal objetivo. Mencionamos ainda que o primeiro é limitado pelo segundo $^{52}$ e pelo princípio da legalidade, sua maior expressão, o que não impediria, no entanto, que o Estado brasileiro constitua o detentor exclusivo tanto do direito de punir quanto do poder de elaboração das regras que o

\footnotetext{
${ }^{49}$ GOMES, Luiz Flávio. Norma e Bem Jurídico no Direito Penal. p. 14.

${ }^{50}$ MIR PUIG, Santiago. El Derecho Penal en el Estado Social y Democrático. p. 159.

${ }^{51}$ ZAFFARONI, Eugenio Raúl. Manual de Direito Penal Brasileiro. p. 86.

${ }^{52}$ NORONHA, Magalhães. Direito Penal: Introdução à Parte Geral. p. 16.
} 
limitam, consistindo na primeira e última organização a sustentar o Direito Penal $^{53}$.

Nada obstante à clara debilidade que já aqui se desenha no princípio da legalidade, é frequente na literatura jurídico-penal que se conceda fins ao ius puniendi com o fito de conceder legitimidade à sua utilização na consecução do manifesto objetivo da exclusiva proteção de bens jurídicos ${ }^{54}$, discussão que se convencionou chamar teoria jurídica da pena ${ }^{55}$. Dito isto, perguntamos: deve-se legitimar e, caso positivo, com base em que pressupostos se concede legitimidade a esse poder-dever, a esse ius puniendi?

A resposta à questão ora formulada teve, como não poderia deixar de ser, duas vertentes basilares: uma negativa e outra positiva. As respostas da vertente negativa, em uma análise meramente jurídica, seriam aquelas fornecidas pelas doutrinas abolicionistas, que almejam a eliminação do Direito Penal e da pena por contestarem tanto o seu fundamento ético político quanto as suas vantagens, quando comparado com os custos causados.

As doutrinas que seguem a vertente positiva, concedendo legitimidade, portanto, aos fins da pena, são divididas em duas: as teorias absolutas ou retributivas, que miram ao passado ao conceber a pena como um fim em si mesmo ${ }^{56}$, e teorias relativas, utilitaristas ou preventivas, que “consideram e justificam a pena enquanto meio para a realização do fim utilitário da prevenção de futuros delitos" ${ }^{\text {, }}$, resumindo-se na meta de

\footnotetext{
53 SALIBA, Marcelo Gonçalves. Justiça Restaurativa e Paradigma Punitivo. Curitiba: Juruá, 2009. p. 31.

${ }^{54}$ RIPOLLÉS, José Luis Diez. El Derecho Penal Simbólico y los Efectos de la Pena. p. 3. Disponível em <www.4shared.com>. Acesso em 10 de abril de 2011.

${ }^{55}$ SANTOS, Juarez Cirino dos. Direito Penal: Parte Geral. p. 420.

${ }^{56}$ ROXIN, Claus. Sentido e Limites da Pena Estatal. Tradução de Ana Natscheradactz e Maria Fernanda Palma. In: BRITO, José (Org.). Problemas Fundamentais de Direito Penal. $3^{\mathrm{a}}$ ed. Lisboa: Vega, 1998. p. 16.

${ }^{57}$ FERRAJOLI, Luigi. Direito e Razão: Teoria do Garantismo Penal. p. 236.
} 
repressão e controle do crime. Jakobs ${ }^{58}$ afirma que tais teorias se reduzem, respectivamente, às formulas latinas punitur, quia pecatum est e punitur, ne peccetur. As doutrinas utilitárias, por fim, podem ser divididas de acordo com os destinatários da sua prevenção em especial e geral, ou de acordo com a natureza da prestação da pena em positiva e negativa ${ }^{59}$.

Impõe-se a análise individualizada de todas ante a grande variedade de respostas. Desde já ressaltamos, contudo, que a discussão ora proposta continuará baseada no entendimento dos fins (manifestos) da pena, enquanto meio de consecução do objetivo manifesto do Direito Penal, razão pela qual nos limitaremos às críticas jurídicas, não criminalistas, de cada tese, inclusive no que diz respeito às doutrinas abolicionistas. Incontestável também a importância prática do tema, em especial quando pautada nele a orientação "político-criminal” brasileira.

\subsection{1 - Teorias abolicionistas: menção necessária}

No que diz respeito à terminologia, introduz Luigi Ferrajoli:

"Considero abolicionistas somente aquelas doutrinas axiológicas que acusam o direito penal de ilegítimo, ou porque moralmente não admitem nenhum tipo de objetivo como capaz de justificar as aflições que o mesmo impõe, ou porque consideram vantajosa a abolição da forma jurídico-penal da sanção punitiva e a sua substituição por meios pedagógicos ou instrumentos de controle do tipo informal e imediatamente social. Ao contrário, não são abolicionistas, e sim, mais propriamente, substitutivas aquelas doutrinas criminologicas que, embora intencionalmente libertadoras e humanitárias, na pratica convergem para o correcionalismo positivista, o qual, sob o programa da 'abolição da pena', propõe, na verdade, a substituição da forma penal de reação punitiva com 'tratamentos' pedagógicos ou terapêuticos de tipo informal, que permanecem, contudo, sempre instutucionalizados e coercitivos e não meramente sociais. Por derradeiro, são simplesmente reformadoras as doutrinas penais que preceituam a redução da esfera de intervenção penal, ou, ainda, a abolição da especifica pena moderna que constitui a reclusão carcerária em favor de sanções penais menos aflitivas" ${ }^{60}$.

\footnotetext{
58 JAKOBS, Günther. Derecho Penal: Parte General. Tradução para o espanhol por Joaquin Contreras e Jose Luis Murillo. 2a ed. Madrid: Marcial Pons, 1997. p. 20.

${ }^{59}$ FERRAJOLI, Luigi. Direito e Razão: Teoria do Garantismo Penal. p. 245. Balestra as divide em "ejecutivas y conminatórias" (BALESTRA, Carlos Fontán. Tratado de Derecho Penal: Tomo I. p. 196.), definições que, ao nosso ver, se misturam com os conceitos de prevenção geral positiva e prevenção geral negativa mencionadas por Ferrajoli.

${ }^{60}$ FERRAJOLI, Luigi. Direito e Razão: Teoria do Garantismo Penal. p. 231.
} 
Numa palavra: antítese. São teorias que diferem inteiramente de todas as outras que, independentemente de suas particularidades, veem na pena um remédio amargo do qual a sociedade não pode se livrar. Ao determinarem a dispensabilidade da pena, conforme Zaffaroni ${ }^{61}$, tais teses passam pela gravidade da utilização simbólica do Direito Penal como instrumento de controle e manutenção das desigualdades, realidade que não compensaria a gravidade dos danos causados.

Na prática, contudo, o conceito da pena como resposta necessária à eventual violação dos bens jurídicos considerados essenciais sempre constituiu elemento determinante no Direito Penal, de épocas primitivas à ao Direito contemporâneo, passando pela idade antiga, direito grego, romano, germânico, hispânico e canônico ${ }^{62}$. Tamanha a relação simbiótica histórica entre pena e Direito Penal que determinados doutrinadores, como Muñoz Conde ${ }^{63}$, afirmam a sua existência como indispensável para o funcionamento dos sistemas sociais de convivência. Em suma, é uma questão extremamente delicada e refinada, sendo pouquíssimos os doutrinadores modernos, mesmo entre adeptos do garantismo ou minimalismo penal, a defendê-la diretamente, como Louk Hulsman ${ }^{64}$ e Passeti $^{65}$.

Zaffaroni, por outro lado, busca minimizar a discussão entre a validade ou invalidade dos discursos abolicionistas observando que as soluções abolicionistas radicais "encontram-se fora da historia, no sentido que são propostas em nível racional, mas que devem ser submetidas à

\footnotetext{
${ }^{61}$ ZAFFARONI, Eugenio Raúl. Manual de Direito Penal Brasileiro. p. 78. Tal tema será melhor abordado quando da análise crítico criminalista da pena.

${ }^{62}$ BALESTRA, Carlos Fontán. Tratado de Derecho Penal: Tomo I. pp. 91-152.

${ }^{63}$ CONDE, Francisco Muñoz. Introducción al Derecho Penal. Barcelona: Bosch, 1975. p. 33.

${ }^{64}$ HULSMAN, Louk. Temas e conceitos numa abordagem abolicionista da justiça criminal. Tradução de Maria de Carvalho. In: PASSETI, Edson (Org.). Conversações Abolicionistas: Uma Crítica do Sistema Penal e da Sociedade Punitiva. São Paulo: IBCCRIM, 1997.

${ }^{65}$ PASSETTI, Edson. A atualidade do Direito Penal. In: PASSETTI, Edson (Org.). Curso Livre de Abolicionismo Penal. Rio de Janeiro: Revan, 2004.
} 
análise", permitindo a "elaboração de uma política criminal alternativa, menos violenta" ${ }^{, 66}$.

\subsection{2 - Teorias absolutas ou retributivas}

É a resposta mais tradicional à pergunta em comento e se baseia na necessidade da retribuição de um mal com outro mal, pura e simplesmente, sem qualquer outro efeito além desse, não conferindo, portanto, legitimidade à pena com base em fins. Tais teorias correspondem à arraigada convicção humana de que nenhum mal deve restar sem castigo, que quem cometeu um delito deve ser castigado. "La pena no aparece entonces como un instrumento dirigido a la consecucion de fines utilitários (...) sino como exigência ética derivada del valor Justicia” ${ }^{67}$, completa Mir Puig. Sustenta-se, portanto, em uma subjetiva noção de justiça que, no decurso da história, já se apoiara em princípios religiosos, morais e jurídicos $^{68}$.

A noção retributiva secular é característica do pensamento teológico basilar do absolutismo pré-modernismo ${ }^{69}$, que, conforme abordaremos mais a frente, entendia a figura do soberano como intrínseca ao próprio conceito de Estado, poder concedido diretamente por Deus. A pena nada mais é, portanto, que o mandato de Deus ${ }^{70}$ ante a violação de sua lei e a expiação do eventual desrespeito aos desideratos divinos que regem o mundo.

Com o advento do modernismo ocorre uma crise do pensamento religioso absolutista, consequência dos novos ideais burgueses fundamentados na teoria do contrato social. O Estado, expressão soberana do povo, não poderia continuar mantendo o fundamento da sua agora exclusiva pretensão punitiva "na já dissolvida identidade entre Deus e

\footnotetext{
${ }^{66}$ ZAFFARONI, Eugenio Raúl. Manual de Direito Penal Brasileiro. p. 79.

${ }^{67}$ MIR PUIG, Santiago. El Derecho Penal en el Estado Social y Democrático. p. 116.

${ }^{68}$ BALESTRA, Carlos Fontán. Tratado de Derecho Penal: Tomo I. p. 194.

69 FERRAJOLI, Luigi. Direito e Razão: Teoria do Garantismo Penal. p. 236. Suas origens, contudo, remetem à idade antiga.

${ }^{70}$ ROXIN, Claus. Sentido e Limites da Pena Estatal. p. 17.
} 
soberano, religião e Estado"71. Passa-se então a conceber a retribuição de duas formas distintas que, apesar de laicas, continuam a compreender a pena como um fim em si mesmo: a retribuição ética e a retribuição jurídica $^{72}$.

A primeira tese, fundada no imperativo categórico cunhado por Kant, entende que a pena se justifica no valor moral da lei transgredida e pelo castigo imposto, sendo, pois, exigência da natureza humana que o mal seja retribuído com o mal e o bem com o com uma recompensa correspondente $^{73}$. O transgressor deveria ser castigado unicamente por ter delinquido, sem qualquer consideração sobre a utilidade da pena para este ou para quaisquer outros integrantes da sociedade, os quais, por sua vez, possuem obrigação castigar o transgressor, sob pena de se tornarem cúmplices dos seus intentos violadores ${ }^{74}$. "Si há matado, debe morir" observa Jakobs, em frase que claramente demonstra uma influência da lei de talião.

A segunda tese, formulada por Hegel, compreende na punição a necessidade do reestabelecimento ordenamento jurídico violado por meio de nova violência, fundamentação que levara Roxin e diversos autores a definir a essência da pena nesta resposta parafraseando a conhecida frase "a pena é uma negação da negação do direito"76. Trata-se de um embasamento retributivo mais jurídico que religioso, ético ou moral, mas que, em sua essência, significa o mesmo: "o crime é aniquilado, negado, expiado pelo sofrimento da pena que, desse modo, restabelece o direito lesado"77.

\footnotetext{
${ }^{71}$ BITENCOURT, Cezar Roberto. Manual de Direito Penal: Parte Geral. p. 68.

${ }^{72}$ FERRAJOLI, Luigi. Direito e Razão: Teoria do Garantismo Penal. p. 237.

73 BALESTRA, Carlos Fontán. Tratado de Derecho Penal: Tomo I. p. 196. O autor a chama também de retribuição moral.

${ }^{74}$ Ibid. p. 196.

${ }^{75}$ JAKOBS, Günther. Derecho Penal: Parte General. p. 21.

${ }^{76}$ ROXIN, Claus. Sentido e Limites da Pena Estatal. p. 16.

${ }^{77}$ Ibid. p. 17.
} 
São diversas as objeções jurídicas formuladas pela doutrina aos postulados básicos das teorias absolutas. Uma delas é a constante confusão que se faz entre o conceito de pena e a sua finalidade; conceitualmente a pena é, de fato, um mal que se impõe por conta da prática de um delito, mas isso não que dizer que o seu fim seja a mera retribuição ${ }^{78}$. Aceitar, então, que o penalizar possua um valor natural e que não busca outro efeito além da justa retribuição dos delitos - pena enquanto "fim em si mesmo" - é supor uma necessidade e não fundamentá-la, é se abster de justificar pena e lei. A respeito, confira-se a sempre válida lição de Carlos Fontán Balestra:

"En lo que respecta a la absoluta necesidad de razón de la ley, es indudable que lo racional se realiza tendiendo a un fin; cuando el fin falta, la acción carece de fundamento y de sentido; decimos que no es racional. De tal suerte, la inexistencia de un fin quita la razón a la ley" 79 .

Como consequência desta capciosa questão lógica, Roxin aduz que tais teorias acabam por se elidir de responder "sob que pressupostos a conduta humana autoriza o Estado a castigar", concedendo, "de certo modo, um cheque em branco ao legislador" ${ }^{\prime 80}$. Nada obstante a tecer críticas veementes à retribuição, Mir Puig aparenta discordar desse argumento ao afirmar haver uma "limitación que dicha teoría impone a la pena: la retribuición se opone a que se castigue más allá que la gravedad del hecho cometido, 81 .

Parece-nos, entretanto, teoricamente irrelevante se as teorias absolutas limitam ou não o exercício da pena, considerando a inidoneidade inicial do seu pressuposto que antecede à aplicação do castigo propriamente dito: a alegada vinculação entre culpa e pena. Fora o próprio Roxin quem

\footnotetext{
78 "Nadie puede negar que la pena es un mal que se impone como consecuencia de um delito. La pena és, sin duda, um castigo. (...) Ahora bien, una cosa es lo que sea pena y otra distinta cuál sea su función y lo que legitima su ejercicio". MIR PUIG, Santiago. El Derecho Penal en el Estado Social y Democrático. p. 119.

${ }^{79}$ BALESTRA, Carlos Fontán. Tratado de Derecho Penal: Tomo I. p. 195.

${ }^{80}$ ROXIN, Claus. Sentido e Limites da Pena Estatal. p. 17-18

${ }^{81}$ MIR PUIG, Santiago. El Derecho Penal en el Estado Social y Democrático. p. 118.
} 
estabelecera, aliás, que "não se compreende como se pode pagar um mal cometido, acrescentando-lhe um segundo mal, sofrer a pena" ${ }^{, 82}$.

\subsection{3 - Teorias relativas, utilitárias ou preventivas}

Como adiantamos, as teorias utilitárias diferem das absolutas por visarem prevenir a prática dos fatos delitivos, e não retribuir um fato delitivo cometido em concreto. Se o castigo ao autor do delito é necessário, segundo as lógicas absolutas, para restabelecer a ordem da valores prévia, nas teorias utilitárias a pena se impõe para evitar a realização dessas condutas violadoras de bens jurídicos que se estimam indesejáveis ${ }^{83}$. Do mesmo modo, se a retribuição absoluta visa o passado e se esgota no castigo pelo feito, a prevenção utilitarista visa o futuro e persegue a inibição de novas violações mediante a cominação de delitos ${ }^{84}$.

Em tempos passados chegou-se a deturpar o cerne das teorias utilitaristas de uma busca, ao menos em tese, "proporcional" da prevenção de futuros delitos, para a prevenção destes através de reações estatais arbitrárias ou excessivas, intento as qualificam como variantes da doutrina

\footnotetext{
${ }^{82}$ ROXIN, Claus. Sentido e Limites da Pena Estatal. p. 19. Luigi Ferrajoli (FERRAJOLI, Luigi. Direito e Razão: Teoria do Garantismo Penal. p. 237), sobre o assunto: “(...) inobstante a autoridade de Kant e de Hegel, tais versões da doutrina retributiva da pena são insustentáveis. Na base de ambas, como observou Morris Grinsberg, existe uma obscura mas radicada crença na existência de um certo nexo necessário entre culpa e punição. Com efeito, trata-se da sobrevivência de antigas crenças mágicas que derivam de uma confusão entre direito e natureza, vale dizer a idéia da pena como restauração ou remédio, ou reafirmação de uma ordem natural violada, ou ainda daquela religiosa do contrapasso e da purificação do delito por meio do castigo, ou aquelas igualmente não razoáveis da negação do direito por parte do erro e da simétrica reparação deste pelo direito (...) Em todos os casos essa distinção primordial da justiça penal é filosoficamente absurda. Assim sendo, continua insuperada a óbvia objeção extraída de Platão de que 'o que foi feito não pode ser desfeito (...)". Zaffaroni (ZAFFARONI, Eugenio Raúl. Manual de Direito Penal Brasileiro. p. 106) completa que a possibilidade de reparação por retribuição existe, mas é característica das ciências não penais; nas suas palavras: "Quando se segrega um agente da administração pública por má conduta funcional, repara-se a imagem da administração, expurgada deste elemento; quando se ordena o pagamento de uma indenização por descumprimento de um contrato, repara-se o dano que o descumprimento causou etc. Esta é a verdadeira sanção retributiva: a sanção não penal, em que a retribuição constitui uma reparação, único sentido em que a retribuição pode ser racional, por que a retribuição pela retribuição mesma não o seria”.

${ }^{83}$ BALESTRA, Carlos Fontán. Tratado de Derecho Penal: Tomo I. p. 196.

${ }^{84}$ MIR PUIG, Santiago. El Derecho Penal en el Estado Social y Democrático. p. 119.
} 
da defesa social ${ }^{85}$. Assim pensar, contudo, é compreender a defesa social em sua definição mais antiga e pejorativa, conforme Marc Ancel ${ }^{86}$ afirmava já em 1954.

As doutrinas utilitárias podem ser divididas de acordo com dois critérios: prevenção especial ou geral, dependendo do círculo de destinatários englobar apenas o infrator ou toda a comunidade, e em positiva ou negativa, dependendo da natureza da prestação da pena.

\subsubsection{1 - Do utilitarismo mediante prevenção especial}

Para os seus adeptos a pena assenta a sua justificação na prevenção de novos delitos por parte do delinquente ${ }^{87}$, o que poderia ocorrer através de três maneiras: intimidando ou advertindo aqueles que são delinquentes ocasionais $^{88}$; ressocializando ou corrigindo, via tratamento, os mesmos delinquentes ocasionais ${ }^{89}$; e tornando "inocuizados", inofensivos, mediante pena privativa de liberdade, aqueles delinquentes contumazes, nem intimidáveis nem corrigíveis $^{90}$. Corresponde esta última à prevenção especial negativa e as duas primeiras à prevenção especial positiva. A consecução de tais objetivos seria atribuição legal tanto dos sujeitos da aplicação penal, mediante sentença individualizada o suficiente para

85 FERRAJOLI, Luigi. Direito e Razão: Teoria do Garantismo Penal. p. 244; BARATTA, Alessandro. Criminología Crítica y Crítica del Derecho Penal: Introducción a la sociologia jurídico-penal. p. 30.

86 "Uma acepção bastante comum - se bem que hoje em dia totalmente ultrapassada - consiste em entender por defesa social a proteção da sociedade contra o crime, na medida em que se procurar obter essa proteção através de uma repressão vigorosa das infrações cometidas. (...) Diversos autores continuaram assim a atribuir ao termo defesa social, unicamente pela comodidade de linguagem, este sentido sinônimo de severidade da repressao." ANCEl, Marc. A Nova Defesa Social: Um Movimento de Política Criminal Humanista. Tradução por Osvaldo Melo. Rio de Janeiro: Forense, 1979. pp. 02-03.

${ }^{87}$ ROXIN, Claus. Sentido e Limites da Pena Estatal. p. 20.

${ }^{88}$ MIR PUIG, Santiago. El Derecho Penal en el Estado Social y Democrático. p. 122.

${ }^{89}$ Ibid. p. 122.

${ }^{90}$ ROXIN, Claus. Sentido e Limites da Pena Estatal. p. 20. 
prevenir o crime ${ }^{91}$, quanto dos sujeitos da execução penal, chamados por Foucault de "ortopedistas da moral" 92 .

Os fundamentos da teoria da prevenção especial procedem do Iluminismo, mas sua aplicação retrocedera no início do século XIX ante uma expansão das teorias retribucionistas, tendo, contudo, retornado com extrema força a partir de 1833 e do "Programa de Marburgo"93 do alemão Von Liszt ${ }^{94}$. Voltara a retroceder na Alemanha graças a novo avanço jurisprudencial da teoria da retribuição ${ }^{95}$, porém ainda possui enorme influência mundo afora graças à "Nova Defesa Social”, do já mencionado Marc Ancel. Diz o penalista a respeito das vertentes negativa e positiva, respectivamente:

“2. ${ }^{\circ}$ Essa proteção social, a Defesa Social tenciona realizá-la, graças, sobretudo a um conjunto de medidas extrapenais; na acepção exata da palavra, destinadas a neutralizar o delinqüente, seja pela 'eliminação' ou pela segregação, seja através de métodos curativos ou educativos; e reencontramos aqui as relações evidentes entre as idéias de defesa social e a noção de periculosidade tal qual a idealizou sobretudo a União Internacional de Direito Penal;

3. A Defesa Social conduz assim à promoção de uma política criminal que atribui uma importância particular à prevenção individual e que se esforça por tornar operante um sistema de 'prevenção do crime e tratamento dos delinquentes'; essa política criminal racional tende conseqüentemente à uma ação sistemática de ressocialização, e mister se faz, desde logo, insistir sobre o valor desta exressão" ${ }^{96}$. (sic)

A doutrina costuma tecer críticas contundentes a ambas as modalidades de prevenção especial por, assim como as teorias da retribuição, não possibilitarem uma delimitação do poder punitivo do Estado $^{97}$. Questiona-se, no que diz respeito à prevenção especial negativa, tanto a arbitrariedade em si contida quanto a idiossincrasia de se considerar como efeito da pena o não cometimento de novos delitos, questão

\footnotetext{
${ }^{91}$ SANTOS, Juarez Cirino dos. Direito Penal: Parte Geral. p. 424.

${ }^{92}$ FOUCAULT, Michel. Vigiar e Punir. pp. 18-23.

${ }^{93}$ MIR PUIG, Santiago. El Derecho Penal en el Estado Social y Democrático. p. 121-122.

${ }^{94}$ LISZT, Franz Von. Tratado de Direito Penal Alemão: Tomo I. p. 156.

${ }^{95}$ ROXIN, Claus. Derecho Penal: Parte General. p. 83.

${ }^{96}$ ANCEl, Marc. A Nova Defesa Social: Um Movimento de Política Criminal Humanista. p. 19.

${ }^{97}$ ROXIN, Claus. Sentido e Limites da Pena Estatal. p. 21.
} 
verdadeira apenas para o exterior da prisão ${ }^{98}$. No tocante à prevenção especial positiva, a maior das críticas jurídicas se refere à legitimidade de se tentar obrigar uma personalidade desviante por meio de projetos autoritários de homologação ${ }^{99}$, educação e tratamento.

\subsubsection{2 - Do utilitarismo mediante prevenção geral}

A segunda das respostas utilitárias à pergunta inicial vê o sentido da pena não na influência, quer retributiva, quer corretiva ou protetora, sobre o próprio agente, concepções que denotam uma ideia de delito como mal intrínsseco ${ }^{100}$, mas sim nos seus efeitos intimidatórios ou confirmatórios sobre a generalidade das pessoas $^{101}$, hipóteses que constituem, respectivamente, as subdivisões negativa e positiva da prevenção geral.

A prevenção geral negativa tem suas bases em Romagnosi ${ }^{102}$, Carrara $^{103}$, e, mais recentemente, na "teoria da coação psicológica" de Feuerbach $^{104}$. "Todas las contravenciones de la ley, según Feuerbach, surgen de la 'sensualidad', es decir, el apetito del hombre se ve impulsado a la comisión por el placer en (o procedente de) la acción" Jakobs. O Estado, ciente desta realidade, prevê a pena abstratamente para intimidar a todos e eventualmente aplica a pena para que reforce a ameaça, desestimulando assim possíveis tentações. É bastante criticada por também não limitar a faculdade de intimidação do Estado, possuindo uma tendência para o "terror estatal""106 ou para, como baliza Ferrajoli, o "terror legislativo",107.

\footnotetext{
${ }^{98}$ SANTOS, Juarez Cirino dos. Direito Penal: Parte Geral. p. 425.

${ }^{99}$ FERRAJOLI, Luigi. Direito e Razão: Teoria do Garantismo Penal. p. 247.

${ }^{100}$ Ibid. p. 255.

${ }^{101}$ ROXIN, Claus. Sentido e Limites da Pena Estatal. p. 23.

${ }^{102}$ ZAFFARONI, Eugenio Raúl; BATISTA, Nilo; ALAGIA, Alejandro; SLOKAR, Alejandro. Direito Penal Brasileiro: primeiro volume - Teoria do Direito Penal. p. 115.

${ }^{103}$ BARATTA, Alessandro. Criminología Crítica y Crítica del Derecho Penal: Introducción a la sociologia jurídico-penal. p. 30.

${ }^{104}$ SANTOS, Juarez Cirino dos. Direito Penal: Parte Geral. p. 426.

105 JAKOBS, Günther. Derecho Penal: Parte General. p. 26.

${ }^{106}$ ROXIN, Claus. Sentido e Limites da Pena Estatal. p. 23.

${ }^{107}$ FERRAJOLI, Luigi. Direito e Razão: Teoria do Garantismo Penal. p. 254.
} 
Já em sua versão positiva a prevenção geral busca confirmar a validade do Direito no imaginário da sociedade. Tal versão possui pelo menos três vertentes distintas descritas na doutrina ${ }^{108}$, variantes que, por sua vez, são classificadas de fundamentadoras - teses de Welzel e Jakobs - ou limitadora da prevenção geral - tese de Roxin. ${ }^{109}$

A primeira tese da prevenção geral positiva fundamentadora, fundada em Welzel $^{110}$, considera a pena como uma matriz que busca reforçar, simbolicamente, os valores ético-sociais em face de ações que contra aqueles atentem. Por considerar tal configuração "demasiado psicologizante" ${ }^{111}$, Jakobs ${ }^{112}$ cria a sua própria vertente fundamentadora que considera a pena não como proteção de valores, mas sim como reafirmação da validade da norma ante a violação praticada, alicerce atacado por fundarse em postulados do contrato social $^{113}$ e por sua clara tendência ao autoritarismo.

Roxin, por fim, cria uma teoria que considera tanto os efeitos preventivos gerais positivos quanto os especiais positivos, bem como a limitação a ser imposta ao Estado durante o exercício do seu papel de protagonista penal e na busca daqueles efeitos. Nas palavras do autor:

108 Enquanto Zaffaroni (ZAFFARONI, Eugenio Raúl; BATISTA, Nilo; ALAGIA, Alejandro; SLOKAR, Alejandro. Direito Penal Brasileiro: primeiro volume - Teoria do Direito Penal. p. 116) descreve as vertentes de Welzel e Jakobs, Juarez Cirino (SANTOS, Juarez Cirino dos. Direito Penal: Parte Geral. p. 426) descreve as vertentes de Roxin e Jakobs. Parece-nos que tal distinção é motivada pelo fato de que o próprio Welzel não considera a sua tese como integrante da prevenção geral, e sim como elemento da retribuição justa.

${ }^{109}$ MIR PUIG, Santiago. El Derecho Penal en el Estado Social y Democrático. p. 132-137. O autor cita ainda outras teses limitadoras, de autoria de Hassemer e Zipf, mas que não foram suficientemente abordadas pela doutrina pátria.

110 “A função ético-social do direito penal, que desejamos resumida, compreende particularmente àqueles indivíduos que, em geral, são capazes de uma relação ético-social. (...) Frente a eles o direito penal atua de modo primário, garantido a segurança e permanência do seu juízo éticosocial, colocando assim os alicerces para um mundo de conceitos morais, e somente depois, secundariamente, nos casos particulares, mediante aplicação da pena por rompimento do direito". WELZEL, Hans. Direito Penal. p. 36.

111 JAKOBS, Günther. Sobre a Teoria da Pena. Tradução de Maurício Lopes. In: LOPES, Maurício (Org.). Estudos de Direito Penal. $1^{\text {a }}$ ed. Barueri: Manole, 2003. p. 26.

112 "Ya de entrada se desenrolló el modélo de una prevencíon geral positiva, es decir, el modelo de una pena cuya fundamentación consiste en ejercitar en el reconocimiento de la norma". JAKOBS, Günther. Derecho Penal: Parte General. p. 26.

${ }^{113}$ SANTOS, Juarez Cirino dos. Direito Penal: Parte Geral. p. 428. 
"Se quiséssemos consagrar numa só frase o sentido e limites do direito penal, poderíamos caracterizar a sua missão como proteção subsidiária de bens jurídicos e prestações de serviços estatais, mediante prevenção geral e especial, que salvaguarda a personalidade no quadro traçado pela medida de culpa individual. Trata-se, se me é permitido dar um nome a esta concepção, de uma teoria unificadora dialéctica, a qual deve ser claramente distinguida, tanto do ponto de vista metodológico quanto pelo seu conteúdo, das tradicionais teorias monistas, assim como da teoria dominante da unificação por adição" ${ }^{, 14}$.

Aqui resumida, tal tese compreende imensa mescla de caracteres específicos, chegando, inclusive, a confundir a mais autorizada doutrina, a qual a denomina prevenção geral positiva limitadora ${ }^{115}$ ou prevenção geral positiva integradora ${ }^{116}$, ignorando que o próprio autor chama-na "teoria unificadora dialética" ou "teoria unificadora preventiva dialética" $" 117$. Apesar de ter tentado, também, evitar que sua teoria caísse na vala comum das teorias mistas ou unificadoras, a serem analisadas de imediato, esta acabara sendo compreendida como variante daquelas ${ }^{118}$.

\subsection{4 - Teorias utilitárias mistas ou unificadoras: a "política criminal" brasileira}

São teorias que, como o nome sugere, unificam as respostas previamente abordadas, retribuição, prevenção especial e prevenção geral, objetivando assim superar as deficiências particulares a cada uma mediante a sobreposição por adição dos seus pontos positivos ${ }^{119}$. Sustenta, em sua configuração principal, que a pena deve "combinar a retribuição de culpabilidade mediante pena com a influência reabilitadora, intimidatória ou de asseguramento no autor concreto" e em "potenciais autores"120, consolidando por completo da meta de repressão da criminalidade e

\footnotetext{
${ }^{114}$ ROXIN, Claus. Sentido e Limites da Pena Estatal. p. 43.

115 MIR PUIG, Santiago. El Derecho Penal en el Estado Social y Democrático. p. 132-137.

${ }^{116}$ Ibid. p. 159; SANTOS, Juarez Cirino dos. Direito Penal: Parte Geral. p. 426; FERRAJOLI, Luigi. Direito e Razão: Teoria do Garantismo Penal. p. 255.

${ }^{117}$ ROXIN, Claus. Derecho Penal: Parte General. p. 95.

${ }^{118}$ JAKOBS, Günther. Sobre a Teoria da Pena. p. 3.

${ }_{119}^{119}$ ROXIN, Claus. Sentido e Limites da Pena Estatal. p. 44.

120 "Isto, por sua vez, significa que a pena adequada à culpabilidade nunca deve ser ultrapassada por razoes preventivas, e que em virtude dessas mesmas razões, por outro lado, nunca somente pode ser fixada uma pena moderadamente inferior à pena adequada à culpabilidade, isto, por exemplo, "para não dificultar ao autor o caminho da reinserção"”. JAKOBS, Günther. Sobre a Teoria da Pena. p. 2.
} 
controle do crime. Não deixam, apesar de conterem pressupostos absolutos, de apelarem para o utilitarismo para conceder legitimidade à pena.

A questão é que todas as teorias que ora se pretende unificar possuem, para cada alegado "ponto positivo", pelo menos uma fragilidade a ser convenientemente explorada pelos que sustentam as teses dualistas, quer absolutas ou unicamente utilitárias. Essa situação de extrema subjetividade do que se consideram por "pontos positivos" das teorias monistas acabou, a nosso ver, tornando a teoria unificadora non gratta na doutrina, recebendo, salvo raras - porém nada inesperadas ${ }^{121}$ - exceções, críticas de ambos os lados.

Nessa perspectiva, costuma-se afirmar que a admissão de diferentes fins à pena criminal através de simples adição de teorias antagônicas não supera as suas fragilidades específicas, resultando, sim, na adição dos seus respectivos equívocos e na possibilidade de escolha o fim mais apropriado ao caso concreto, o que seria inaceitável ${ }^{122}$. Assevere-se mais, como remate: as teorias unificadoras sequer apresentam o elemento de coesão a resultar na pretensa harmonia entre absolutas e utilitárias ${ }^{123}$.

\footnotetext{
121 "Retribui-se porque se apurou ser fulano o responsável pelo fato provado, mas visando sua ressocialização, com base na prevenção geral e especial, de molde que estará socializado aquele que não mais cometer novo delito. (...) Assim, propomos a seguinte solução ao problema da questão da finalidade da pena: o direito penal se fundamenta quando seu exercício, ou seja, a diminuição de um direito, tiver o objetivo de recuperar o cidadão e prevenir potenciais criminosos na prática de futuros ilícitos. Descabe, pois, qualquer consideração de retribuição-castigo, mas apenas no sentido de retribuição-normativa. A medida da sanção é a prevenção geral e não a culpabilidade, que configura o seu mero pressuposto". O ilustre magistrado Fausto de Sanctis (DE SANCTIS, Fausto Martin. Fins da pena criminal: repressão ou prevenção?. Disponível em <www.ibccrim.com.br>. Acesso em 10 de abril de 2011) aparenta compreender a finalidade retributiva em seu sentido jurídico-hegeliano, entendimento defensável não fosse a, data venia, "curiosa" afirmação anterior.

${ }^{122}$ ROXIN, Claus. Derecho Penal: Parte General. p. 94; ROXIN, Claus. Sentido e Limites da Pena Estatal. p. 44; JAKOBS, Günther. Sobre a Teoria da Pena. p. 5; SANTOS, Juarez Cirino dos. Direito Penal: Parte Geral. p. 430; ZAFFARONI, Eugenio Raúl; BATISTA, Nilo; ALAGIA, Alejandro; SLOKAR, Alejandro. Direito Penal Brasileiro: primeiro volume - Teoria do Direito Penal. p. 114.

${ }^{123}$ JAKOBS, Günther. Sobre a Teoria da Pena. p. 5; SANTOS, Juarez Cirino dos. Direito Penal: Parte Geral. p. 431.
} 
A despeito das objeções formuladas, fato é que teoria da união recém esboçada predomina na prática penal ocidental. São nítidos os seus reflexos, por exemplo, no Código Penal alemão (Strafgesetzbuch); vide $§ 46$, que mescla a culpabilidade como fundamento da pena com os efeitos à vida futura do autor, e $\S 47$, que trata da defesa da ordem jurídica, elementos característicos, respectivamente, das teorias da retribuição, prevenção especial, e prevenção geral ${ }^{124}$.

Assim prevendo a legislação, nada mais natural que a Corte Constitucional alemã assegurasse a exegese dessas teorias, o que tem feito sem floreios ao decidir que a pena criminal é, sem prejuízo de intimidar e ressocializar, retribuição pelo injusto cometido ${ }^{125}$. Chegara até a afirmar, por ocasião de outra decisão, que como aspectos de uma pena adequada devem estar a compensação da culpabilidade, a prevenção, a ressocialização do sujeito, a expiação e a retribuição pelo injusto cometido ${ }^{126}$.

O Código Penal brasileiro, a exemplo do alemão e em abono do princípio da legalidade, também adota as teorias unificadas em seu artigo $59^{127}$, que menciona a necessidade de fixação da pena de acordo com a culpabilidade e de modo suficiente para a reprovação e prevenção do crime, ideias que remetem à retribuição, à prevenção lato sensu e constituem a "política criminal" oficial do Estado. Confiramos, neste sentido, alguns julgados do Supremo Tribunal Federal que evidenciam de que forma a “moderna política criminal” brasileira é executada:

“(...) 2.3 Cuidando-se exclusivamente de definir a execução da pena de prisão imposta, o apelo exclusivo a gravidade da culpa não basta para fundar com razoabilidade a imposição do regime inicial mais gravoso: e a prevenção geral

\footnotetext{
${ }^{124}$ SANTOS, Juarez Cirino dos. Direito Penal: Parte Geral. p. 429.

${ }^{125}$ BUNDESVERFASSUNGSGERICHT, Decisão 39, 1, 57. In: ROXIN, Claus. Derecho Penal: Parte General. p. 94.

126 BUNDESVERFASSUNGSGERICHT, Decisão 45, 187, 253. In: ROXIN, Claus. Derecho Penal: Parte General. p. 94.

${ }^{127}$ Art. 59 - O juiz, atendendo à culpabilidade, aos antecedentes, à conduta social, à personalidade do agente, aos motivos, às circunstâncias e conseqüências do crime, bem como ao comportamento da vitima, estabelecerá, conforme seja necessário e suficiente para reprovação e prevenção do crime.
} 
que domina a cominação legal da pena em abstrato e igualmente demarca os limites possiveis de sua individualização, no momento da aplicação judicial; mas, e patente que, aplicada a pena na sentença, ganha peso dominante a ponderação dos interesses da prevenção especial, já na verificação da conversibilidade da pena corporal de curta duração em sanções substitutivas, ja, não sendo o caso de substituição, no momento final do processo de concretização de norma penal, que e o da definição do regime executivo da privação de liberdade" ${ }^{\text {"128 }}$.

“(...) 4. Era perfeitamente compatível com a Constituição Federal a vedação da progressão do regime de cumprimento da pena quando da condenação por prática de crime hediondo ou a ele equiparado. Daí a consideração de que o tema referente ao regime de cumprimento da pena corporal ser apenas um dos aspectos relativos à execução penal, perfeitamente adequado à realidade dos crimes reputados mais danosos à sociedade, em postura normativa perfeitamente coerente com a finalidade retributiva da pena (...)",129.

O Exc. Pretório, diferentemente do seu correspondente alemão, parece concretizar os temores daqueles que vêem nas teorias unificadoras a possibilidade de que se escolha, in casu, o fim mais adequado ${ }^{130}$ à suposta pretensão utilitária de controlar o crime e a criminalidade. Trata-se de uma realidade que alude aos três fatos naturalísticos que compõe a ciência penal, previamente citados no intróito do presente capítulo ${ }^{131}$ : prevenção geral negativa mediante tipificação, pelo Estado, dos atos tidos como criminosos; retribuição e prevenção geral positiva mediante aplicação da pena ao eventual autor de um crime, após juízo de valor oficial do Estado; e prevenção especial positiva mediante execução, pelo Estado, da medida repressiva previamente cominada ao autor considerado culpado.

Os breves conceitos até o momento expostos compõem grandessíssima parte do que se costuma lecionar a respeito de objetivo e legitimidade no Direito Penal. Autores consideravelmente autorizados ${ }^{132}$, pautados pela didática "manualesca" que impera, introduzem a definição da ciência e despejam classificações e parâmetros de aplicação meramente "tecnicistas", desinteressados com o que há de dissimulado e obscuro. O

${ }^{128}$ STF, HC 70362-RJ, 1a T., Rel. Ministro Sepúlveda Pertence. DJ 12.04.96.

${ }^{129}$ STF, RE 552545-MG, $2^{\text {a }}$ T., Rel. Ministra Ellen Gracie. DJ 20.11.08.

${ }^{130}$ ZAFFARONI, Eugenio Raúl; BATISTA, Nilo; ALAGIA, Alejandro; SLOKAR, Alejandro. Direito Penal Brasileiro: primeiro volume - Teoria do Direito Penal. p. 114.

${ }^{131}$ SANTOS, Juarez Cirino dos. Direito Penal: Parte Geral. p. 429.

${ }^{132}$ Cite-se, por exemplo: BITENCOURT, Cezar Roberto. Manual de Direito Penal: Parte Geral; NORONHA, Magalhães. Direito Penal: Introdução à Parte Geral. 
estudo do Direito Penal, contudo, não pode se limitar aos objetivos manifestos e aos fins que o legalismo impõe à pena sob o pretexto de alcançá-los, mas sim permear as reais intenções e funções exercidas pelo utilitarismo formal. 


\section{Capítulo 2 - Objetivos reais ou latentes: Direito Penal, controle social e manutenção do status quo}

Desde a antiguidade que filósofos e sociólogos buscam uma explicação para a clara tendência humana de se agrupar com semelhantes durante a sua existência, constituindo, assim, uma sociedade, termo que vem do latim societas e significa "reunião de homens que vivem em grupos organizados" $"$. A primordial distinção entre as principais proposições oferecidas reside na influência - ou falta de influência - volitiva do homem na sua constituição: enquanto alguns, como Aristóteles ${ }^{134}$, entendem que a sociedade é fruto da própria natureza humana, outros, como Thomas Hobbes $^{135}$, veem na sociedade um acordo de vontades, um contrato hipotético.

Seja a vida em sociedade fruto da natureza ou da vontade humana, são notórios os seus benefícios ao desenvolvimento e perpetuação da espécie, bem como, paradoxalmente, evidentes as sérias limitações à própria liberdade dos indivíduos a ela vinculadas ${ }^{136}$, sob o manifesto pretexto de evitar a ocorrência de conflitos. É que as relações em sociedade são dotadas de extrema precariedade, em grande parte graças aos interesses e vontades antagônicas dos indivíduos que, paralelamente, constituem grupos de acordo com os seus respectivos interesses e vontades. Tais conflitos, sempre presentes independente de época, cultura ou modelo político da sociedade analisada, usualmente se resolvem de modo a configurar uma estrutura de poder em que grupos controlam e grupos são controlados, com grupos mais próximos do poder e grupos mais

\footnotetext{
133 Dicionário Enciclopédico Koogan-Larousse: Volume I. Rio de Janeiro: Larousse do Brasil, 1978. p. 817.

134 “(...) el hombre es um ser naturalmente sociable (...)”. ARISTÓTELES. Política: Livro I. p. 11. Disponível em <www.4shared.com>. Acesso em 15 de maio de 2011.

${ }^{135}$ HOBBES, Thomas. Leviatã. São Paulo: Martins Fontes, 2003. p. 148.

${ }^{136}$ DALLARI, Dalmo de Abreu. Elementos de Teoria Geral do Estado. p. 9.
} 
marginalizados do poder $^{137}$, dominação que, a priori, se estabelece de acordo com a capacidade econômica ou política de cada grupo.

As estratégias de controle social são numerosas e exercidas por diferentes instituições e organizações, sejam elas formais ou não, sempre com o fito de manter o padrão do grupo social mais forte e a exclusão das classes marginalizadas $^{138}$, perpetuando o status quo. Dentro desses amplos mecanismos de controle social incluem-se, atualmente, meios difusos, como a família, meios de comunicação ${ }^{139}$, a atividade artística, a investigação cientifica $^{140}$, e meios institucionalizados, como a educação, a medicina, a religião, os partidos políticos e, especialmente, o Direito e o Direito Penal $^{141}$.

De feições tão sociológicas quanto políticas, a afirmação de que há controle social de um grupo por outro atinge de pronto ideologias pessoais, regra da qual não se furta a menção aos efeitos penais do controle. Inclusive, os primeiros autores a mencionar pejorativamente este efeito e a afirmá-lo como objetivo latente do Direito Penal foram os precursores da chamada criminologia crítica $^{142}$ ou radical ${ }^{143}$, tendência doutrinária que assimila a integração da biologia, psicologia e sociologia com as ciências criminais e adiciona parâmetros de análise assumidamente marxistas, em

\footnotetext{
${ }^{137}$ ZAFFARONI, Eugenio Raúl. Manual de Direito Penal Brasileiro. p. 61.

${ }^{138}$ SALIBA, Marcelo Gonçalves. Justiça Restaurativa e Paradigma Punitivo. p. 31.

${ }^{139}$ SANTOS, Juarez Cirino dos. Direito Penal: Parte Geral. p. 09.

${ }^{140}$ ZAFFARONI, Eugenio Raúl. Manual de Direito Penal Brasileiro. p. 61.

${ }^{141}$ SALIBA, Marcelo Gonçalves. Justiça Restaurativa e Paradigma Punitivo. p. 32.

142 "Cuando hablamos de criminología crítica, y dentro de este movimiento nada homogéneo del pensamiento crimino lógico contemporáneo situamos el trabajo que se está haciendo para la construcción de una teoría materialisa, es decir económico-política, de la desviación, de los comportamientos socialmente negativos y de la criminalización, un trabajo que tiene en cuenta instrumentos conceptuales e hipótesis elaboradas en el ámbito del marxismo (...)" BARATTA, Alessandro. Criminología Crítica y Crítica del Derecho Penal: Introducción a la sociologia jurídico-penal. p. 165.

143 "O objeto geral da Criminologia Radical são as relações sociais de produção (estrutura de classes) e de reprodução político-jurídica (superestruturas de controle), que produzem e reproduzem, através dos processos de criminalização e de execução penal, o objeto específico de conhecimento: o crime e o controle do crime". SANTOS, Juarez Cirino dos. A Criminologia Radical. Rio de Janeiro: Forense, 1981. p. 26.
} 
contraposição às teorias criminológicas clássicas, tradicionais ou liberais ${ }^{144}$, unicamente legitimadoras da realidade dissimulada e fundadas na teoria jurídica da pena. Falamos em precursores, no entanto, por entendermos que a tentativa de compreensão plena do controle social deve ultrapassar eventuais limitações impostas pelo marxismo criminológico, apesar dos grandes avanços por elas trazidos, em especial no que diz respeito à superação das teses que advogam legitimidade, mas apenas criam uma legitimação.

Já não podemos mais vincular a crítica criminológica à existência de "acumulação de riquezas", "modo de produção", "forças produtivas", "relações de produção" ou "luta de classes"145, expressões criadas séculos atrás para evidenciar mazelas verdadeiramente inerentes ao capitalismo. Se o século XX trouxe a crise do capitalismo liberal e a aplicação prática de novos modelos de Estado (à direita e à esquerda) formalmente alheios ao liberalismo econômico, como o nazismo de Hitler, a "ditadura do proletariado” de Stalin, a retórica de Mao Tsé-Tung e a República de Fidel Castro, não demonstrara empiricamente de que forma superar o controle social por via do Direito Penal, além de ter carregado à lambuja "ene" outras utilizações ainda mais violentas da ciência, cuja enumeração foge ao nosso propósito. Não que, nos casos de esquerda, ignoremos o papel da violência oficial como catalisador na superação das contradições de classes. A questão é que, mesmo após a sua formal contração, a violência continuara a servir aos propósitos do poder agora dominante, em contradição ao que se esperava dela em uma revolução ${ }^{146}$.

\footnotetext{
144 "Há uma 'criminologia positivista' ou 'tradicional' que estuda as condutas dos criminalizados e que, ao deixar o sistema penal fora de seu objeto, está aceitando a ideologia veiculada por ele, desta maneira convertendo-se em uma ideologia de justificação do sistema penal e do controle social de que este forma parte". ZAFFARONI, Eugenio Raúl. Manual de Direito Penal Brasileiro. p. 158.

${ }_{145}$ SANTOS, Juarez Cirino dos. Direito Penal: Parte Geral. pp. 06-09.

146 ARENDT, Hannah. Da Violência. Tradução por Maria Drummond. pp. 9-10. Disponível em <www.4shared.com>. Acesso em 13 de maio de 2011.
} 
Parece-nos, de fato, que a existência de grupos controladores e controlados e a utilização do Direito Penal neste violento contexto independe da descentralização da economia, constatada a sua presença, com as devidas especificidades, em países de economia centralizada ${ }^{147}$. A humanidade ainda encontra-se em débito com a aplicação prática de um modelo de Estado em que o monopólio da força não se desenvolva voltado para a manutenção do status quo vigente, razão da complexidade de estabelecer limites entre as novas tendências criminológicas; em certa medida, todas são "críticas" políticos do liberalismo que baseiam a sua forma radical.

Continuam com validade e plena adoção, não obstante, as conclusões marxistas que conectam a institucionalização do Direito Penal em instrumento de controle social ao modernismo e, consequentemente, aos primórdios do capitalismo, como veremos a seguir.

\section{1 - Modernismo, institucionalização do castigo e o paradigma de protagonismo do Estado}

O delito pode, criminologicamente, ser conceituado como " $l a$ sintesis histórica de lo que las sociedades prohiben bajo pena, queriendo claramente significar "lo ilicito",149. Costuma-se considerar o seu surgimento quando o primeiro homem violou, nas relações com seus pares, determinado princípio primitivo considerado como essencial, incorrendo contra o transgressor alguma das diversas formas da pena, elemento diferencial mais típico do Direito Penal ${ }^{150}$.

A sanção penal, em tão longínquos tempos, nada mais era que uma vendetta pessoal motivada pura e simplesmente por instintos e desejos

\footnotetext{
${ }^{147}$ ZAFFARONI, Eugenio Raúl. Manual de Direito Penal Brasileiro. p. 63.

${ }^{148}$ Ibid. p. 159.

${ }^{149}$ SOLER, Sebastian. Derecho Penal Argentino: Tomo I. p. 30.

${ }^{150}$ BALESTRA, Carlos Fontán. Tratado de Derecho Penal: Tomo I. p. 91.
} 
egoísticos, fundamentada usualmente na proteção familiar ${ }^{151}$, realidade que a tornaria suscetível à arbitrariedade e desproporcionalidade. Sustentam alguns que o princípio básico limitador desta vingança privada coincidiria com o conceito do ius talionis, de uma punição nem melhor nem pior que o eventual dano causado ${ }^{152}$, argumento severamente descartado por quem crê que as discórdias entre famílias perduravam por gerações, através do que seriam aplicações em série do talião ${ }^{153}$.

De lá para cá, no entanto, o instituto da coerção punitiva passara por diversos períodos existenciais que se sucederam ou coexistiram ${ }^{154}$, chegando a um momento em que deixara de representar um aspecto meramente regulatório das faculdades dos indivíduos que integram uma sociedade para constituir uma atividade estatal formal, a ser realizada manifestamente, claro - no interesse de todos os cidadãos ${ }^{155}$. Esse fenômeno da monopolização do emprego da força física nas mãos do Estado ocorrera de forma paralela ao nascimento de sua concepção moderna, bem como em abono do que os jusnaturalistas adeptos do contratualismo compreendiam como uma de suas finalidades:

“(...) desde Hobbes, para quem do estado (de terror) da natureza se chegaria à sociedade ou ordenação civil, outorgando-se ao soberano o monopólio da violência; passando por Locke, que elabora as bases do pensamento liberal referido a um contrato que legitimaria o poder apenas na medida em que este servisse para regular ou supervisionar os Direitos naturais, para cuja definição se formaria o pacto; e culminando com Rousseau, para quem o pacto social não tem como objeto a defesa dos interesses individuais, que seria algo mais que a soma dos interesses individuais" 156 .

\footnotetext{
${ }^{151}$ PACHUKANIS, Evgeny Bronislavovich. Teoria Geral do Direito e Marxismo. p. 119.

${ }^{152}$ NORONHA, Magalhães. Direito Penal: Introdução à Parte Geral. p. 29; BALESTRA, Carlos Fontán. Tratado de Derecho Penal: Tomo I. p. 95.

${ }^{153}$ PACHUKANIS, Evgeny Bronislavovich. Teoria Geral do Direito e Marxismo. p. 119.

${ }^{154}$ NORONHA, Magalhães. Direito Penal: Introdução à Parte Geral. p. 28.

155 Não nos referimos à pena puramente pública, que fora exercida de períodos que vão da antiguidade à idade média. Essas, diferentemente da pena institucionalizada, eram exercidas por clérigos e soberanos manifestamente em defesa das divindades e dos seus coroados, não da sociedade como um todo. PACHUKANIS, Evgeny Bronislavovich. Teoria Geral do Direito $e$ Marxismo. pp. 121-122.

${ }^{156}$ CASTRO, Lola Aniyar. Criminologia da Libertação. Tradução de Sylvia Moretzsohn. Rio de Janeiro: Revan, 2005. p. 131.
} 
Tal inédita edificação do Estado como de Direito (também chamado de Liberal $^{157}$ ou Liberal de Direito ${ }^{158}$ ) está intimamente alinhada com o contemporâneo processo histórico de instauração do modernismo, bem como do desenvolvimento do modo de produção capitalista, era cujo longo e gradual marco contara com o suporte intelectual de diversos filósofos e pensadores, como os citados Thomas Hobbes (1588-1679), John Locke (1632-1704) e Jean-Jacques Rousseau (1712-1778) ${ }^{159}$.

Tem-se conceituado o citado modernismo como um "conjunto de transformações culturais, sociais e econômicas, bem como políticas, que haveriam de se produzir (...) entre os séculos XVII e XIX" ${ }^{\prime 160}$. O elemento basilar da metamorfose em voga constituiu, sinteticamente, uma quebra do paradigma teocêntrico do período pré-moderno e o consequente estabelecimento do antropocentrismo como novo modelo de padrão teórico, tudo em prol da razão e do saber como conquistas e pressupostos da nova sociedade. É o discurso característico de uma cultura liberal e burguesa que experimentava um período de enorme acumulação de riquezas e transformação das relações sociais.

O Direito, nesse processo, teve o papel de consolidar o monopólio das suas fontes na formalidade das mãos do Estado ${ }^{161}$, desvalorizando, outrossim, as fontes espontâneas vigentes no período absolutista e monárquico pré-moderno, i.e. “... a unidade entre a moral e o Direito, entre o Estado e a religião, além da metafísica afirmação de que o poder do soberano lhe era concedido diretamente por Deus"162. Nas entrelinhas: as

\footnotetext{
${ }^{157}$ MIR PUIG, Santiago. El Derecho Penal en el Estado Social y Democrático. pp. 31-32.

158 SILVA, José Afonso da. Curso de Direito Constitucional Positivo. $29^{\mathrm{a}}$ ed. São Paulo: Malheiros, 2007. p. 112.

159 SALIBA, Marcelo Gonçalves. Justiça Restaurativa e Paradigma Punitivo. p. 33. O autor cita ainda: Jean Bodin (1530-1596), Nicolau Maquiavel (1469-1527), Adam Smith (1723-1790), Montesquieu (1689-1755), Immanuel Kant (1724-1804), Hegel (1770-1831) e Karl Marx (18181883).

${ }^{160}$ BITTAR, Eduardo C. B. O Direito na Pós-Modernidade. Rio de Janeiro: Forense Universitária, 2005. p. 35.

${ }^{161}$ FERRAJOLI, Luigi. Direito e Razão: Teoria do Garantismo Penal. p. 210.

${ }^{162}$ BITENCOURT, Cezar Roberto. Manual de Direito Penal: Parte Geral. p. 67.
} 
teses contratualistas jusnaturalistas sustentaram o Estado de Direito e restaram, por assim dizer, "traídas" pelas teses juspositivistas defensoras do Estado como origem formal de todo o Direito, contradição chamada por Ferrajoli de “"paradoxo hobbesiano' e a fundação jusnaturalista do Estado de direito" $" 163$.

Essa nova afirmação do sistema legal fora o que o transformara em aparato de sustentação do novo pensamento liberal característico da sociedade em ascensão, concedendo ele papel determinante na imposição e manutenção da nova ordem vigente por meio da "segregação, a má distribuição de rendas, a injustiça social, a inacessibilidade do Estado às demandas sociais" $" 164$, objetivos a serem alcançados sobretudo com o auxílio da repressão penal exclusivamente estatal. O monopólio legítimo da forma se concentrara nas mãos de um Estado, supostamente neutro, mas voltado para a proteção do status $q u o^{165}$.

A despeito de utilizarem o Direito Penal como instrumento de controle social institucionalizado, imprescindível mencionar que os idealizadores do Estado Moderno possuem méritos na concepção de um modelo estatal que, ao menos sob o aspecto teórico, sujeita o seu exclusivo ius puniendi a parâmetros, limitações e controles, em contraposição ao prévio Estado absolutista monárquico; trata-se de um avanço mencionado, inclusive, pelo criminólogo crítico Pachukanis ${ }^{166}$. Mir Puig acrescenta

\footnotetext{
163 “ (...) é, em certa medida, comum a todo o pensamento do Iluminismo: jusnaturalista, vez que voltado a encontrar, no direito natural, os fundamentos do Estado e seus princípios de justificação externa, mas, ao mesmo tempo, positivista, na medida em que tais fundamentos externos, a começar do convencional principio da legalidade, valem exatamente para fundar, alem de limitar e modelar, o direito estatal positivo, enquanto único direito vigente". FERRAJOLI, Luigi. Direito $e$ Razão: Teoria do Garantismo Penal. p. 210-211.

${ }_{164}^{164}$ BITTAR, Eduardo C. B. O Direito na Pós-Modernidade. pp. 56-58.

165 SULOCKI, Victoria-Amália de. Segurança Pública e Democracia: Aspectos Constitucionais das Políticas Públicas de Segurança. p. 197.

166 "No que concerne em particular aos métodos próprios da política penal é importante destacar os progressos alcançados pela sociedade burguesa (...) quando adotou penas mais humanas: abolindo a tortura, as penas corporais, as penas infamantes, as bárbaras execuções capitais etc. Tudo isso representou um grande progresso". O autor se refere, bom dizer, aos países burgueses em geral e nos primórdios do modernismo. Todos os métodos citados voltaram, em maior ou menor escala, a
} 
ainda, mais recentemente, que "el Estado liberal responde a la preocupación de defender a la sociedad del Estado (...) mediante la técnica formal de la división de poderes y principio de legalidad", bem como pelos princípios de "exclusiva protección de bienes jurídicos, de proporcionalidade y culpabilidad"167.

Todavia, na prática, até hoje o já levemente abordado conceito de bem jurídico não fora definido de modo a satisfazer a sua pretensão de delimitar juridicamente ${ }^{168}$ a punição estatal, restando a definição de crime refém das distorções egoístas do legislador ou da justiça criminal $^{169}$; caso da Lei dos Crimes Hediondos, "produto grotesco da imaginação punitiva do legislador brasileiro" ${ }^{, 170}$, e de muitos outros que serão abordados no terceiro capítulo. A proporcionalidade da pena, da mesma forma, nada mais fora que meio de legitimação do cerceamento da liberdade pessoal pela violação do direito de propriedade, bem jurídico essencial à acumulação de riquezas $^{171}$.

Confira-se, apenas a título de remate, a esclarecedora lição de Julio Maier sobre o tema, redigida de maneira a resumir todo o padrão aqui esgrimido, da transferência do poder de punir para o Estado ao objetivo latente de controle social por via do Direito Penal:

"Tal transformacion fundamental se vincula con una reforma profunda de la organización social: la creacion del poder político central, ausente en las sociedades primitivas, esto es, la aparicíon en escena del Estado nacional como

serem utilizados posteriormente. PACHUKANIS, Evgeny Bronislavovich. Teoria Geral do Direito e Marxismo. p. 124.

${ }^{167}$ MIR PUIG, Santiago. El Derecho Penal en el Estado Social y Democrático. pp. 32-37.

${ }^{168}$ ROXIN, Claus. Derecho Penal: Parte General. p. 54.

${ }^{169}$ Sobre o assunto, vide: SANTOS, Juarez Cirino dos. A Criminologia Radical. p. 08; SOARES, Orlando. Causas da Criminalidade e Fatores Criminológicos. p. 25. Ambos os autores tecem críticas apenas à distorcida política de criminalização, e não à teoria do bem jurídico em si. Juarez Cirino (SANTOS, Juarez Cirino dos. Direito Penal: Parte Geral. pp. 14-18), inclusive, considerando todas as limitações e críticas, reafirma a importância do bem jurídico como garantia política irrenunciável do Estado Democrático de Direito, enquanto critério de criminalização e objeto de proteção do Direito Penal.

${ }^{170}$ Ibid. p. 06.

${ }^{171}$ BARATTA, Alessandro. Criminología Crítica y Crítica del Derecho Penal: Introducción a la sociologia jurídico-penal. p. 210. 
forma política que enfrenta y desplaza a la organizacion feudal o local primitiva. La transformación consiste, basicamente, en expropriar a los ciudadanos el poder de reacionar contra el ofensor y mandar a ciertos órganos del Estado a proceder de oficio (per inquisitionem), sin esperar ni atender a la voluntad de los individuos (per accusationem), por una parte, y en instituir a la pena y al Derecho Penal, en general, como un poder del Estado - sin duda, al arma más vigorosa y fuerte para el control formal de los habitantes" $" 172$.

\section{2 - Duas críticas criminológicas, uma desconstrução da legitimidade: descortinando a legitimação com o estudo das funções da pena}

Como visto até o momento, controle social institucionalizado - ou formal, no dizer de Maier - é a resposta geral da criminologia crítica aos questionamentos sobre os objetivos latentes do Direito Penal, em severa negação à declarada proteção dos bens jurídicos relevantes. Paralelamente, como não poderia deixar de ser, a legitimidade da pena realizada pelo discurso jurídico oficioso descumpre os fins utilitários por ele descritos, que são diametralmente opostos às funções reais da pena ${ }^{173}$.

Sem prejuízo de repetir a advertência, por nós já feita, a respeito da possível superação da análise puramente marxista ou radical da criminologia crítica, faz-se necessária sucinta referência ao raciocínio

lógico que fez com que doutrinadores ${ }^{174}$ chegassem à concepção do Direito Penal como um dos principais pilares de legitimação, não legitimidade, ao projeto capitalista de manutenção, como leciona Baratta, "de las relaciones

\footnotetext{
${ }^{172}$ MAIER, Julio. Derecho procesal penal: Tomo I. $2^{\mathrm{a}}$ ed. Buenos Aires: Editores del Puerto, 1999. p. 814.

${ }^{173}$ ANDRADE, Vera Regina Pereira. A Ilusão de Segurança Jurídica: Do controle da violência à violência do controle penal. p. 291.

${ }^{174}$ FOUCAULT, Michel. Vigiar e Punir; BARATTA, Alessandro. Criminología Crítica y Crítica del Derecho Penal: Introducción a la sociologia jurídico-penal; SANTOS, Juarez Cirino dos. Direito Penal: Parte Geral; SULOCKI, Victoria-Amália de. Segurança Pública e Democracia: Aspectos Constitucionais das Políticas Públicas de Segurança.
} 
de poder y propriedad existentes" ${ }^{\text {175 }}$, bem como através de quais efeitos reais se alcançaria tal meta.

Para esses autores, "a pretensa humanização da punição nada mais era que uma nova forma de controle social mais eficiente, condizente com a nova ordem burguesa que se instalava no poder"176, objetivando "preservar a divisão de classes da estrutura social, mediante a ameaça permanente de violência contra a força de trabalho" ${ }^{\prime 177}$. O mesmo processo capitalista que vincularia o proletário ao trabalho o dirigiria para o crime, naqueles casos em que a sua exclusão da força de trabalho ativa o obrigasse a buscar sobrevivência em meios ilegítimos para compensar a falta dos legítimos ${ }^{178}$. Essa criminalização dirigida seria obtida, sobretudo, através do caráter fragmentário do Direito Penal, o qual permitiria a ocultação dos interesses das classes dominantes e a tipificação de comportamentos típicos das dominadas ${ }^{179}$.

A obra "Teoria Geral do Direito e Marxismo" estabelecera alguns dos alicerces $^{180}$ dessa abordagem criminológica de forte influência ideológica, nada obstante ao autor, o já outras vezes citado Pachukanis, ter, ironicamente, desaparecido décadas após a sua elaboração durante as repressões stalinistas de $1937^{181}$. Alguns dos fundamentos desse modelo de

175 BARATTA, Alessandro. Principios de Derecho Penal Mínimo. In: BARATTA, Alessandro (Compilação in memoriam). Criminología y Sistema Penal. p. 301.

176 SULOCKI, Victoria-Amália de. Segurança Pública e Democracia: Aspectos Constitucionais das Políticas Públicas de Segurança. p. 169.

${ }^{177}$ SANTOS, Juarez Cirino dos. A Criminologia Radical. p. 18.

178 Ibid. p. 29.

${ }^{179}$ Ibid. p. 32.

180 “(...) fundamentalmente, isto é, do ponto de vista puramente sociológico, a burguesia assegura e mantém o seu domínio de classe mediante seu sistema de Direito penal, oprimindo as classes exploradas. Sob esta perspectiva os seus tribunais e as suas organizações privadas 'livres' de furadores de greve prosseguem num único e mesmo objetivo (...) As Teorias do Direito penal, das quais se deduzem os princípio da política penal dos interesses da sociedade no seu conjunto, constituem deformações, conscientes ou não, da realidade. 'A sociedade no seu conjunto' existe apenas na imaginação dos juristas; de fato, existem somente classes que tem interesses opostos, contraditórios. Todo determinado sistema histórico de política penal traz as marcas dos interesses de classe que o realizou". PACHUKANIS, Evgeny Bronislavovich. Teoria Geral do Direito e Marxismo. p. 124.

${ }^{181}$ Ibid. p. 5. 
criminologia crítica continuam com grande validade teórica, quiçá prática, graças, em parte, à honesta constatação de que o sistema de produção capitalista não sofrera grandes modificações desde então. Confira-se, por exemplo, alguns trechos da obra brasileira "A Criminologia Radical", de Juarez Cirino, defensor notável dessa abordagem:

"O processo de criminalização (produção e aplicação de normas penais) protege, seletivamente, os interesses das classes dominantes, pré-seleciona os indivíduos estigmatizáveis (classes dominadas) e administra a punição pela posição de classe (variável independente), complementada pela posição precária no mercado de trabalho e pela subsocialização (variáveis intervenientes). $O$ processo de execução penal (sistema carcerário) reproduz as desigualdades sociais (separação trabalhador-meios de produção) e a marginalização (qualificação negativa pela posição estrutural (fora do mercado de trabalho) e pela imposição superestrutural (dentro do aparelho punitivo) de sanções)" ${ }^{182}$. (sic)

Elabora-se, com base nessa linha de pensamento, uma crítica materialista e dialética ${ }^{183}$ da pena, em contraposição às teorias jurídicas vigentes. Para ela, as funções reais ou latentes da pena são o tempo de privação de liberdade como retribuição equivalente ao valor de troca nas relações capitalistas vigentes ${ }^{184}$, legitimada pela manutenção da disciplina da classe trabalhadora e preservação simbólica da ordem social via, respectivamente, os fins utilitários da prevenção especial e prevenção geral $^{185}$, realidade que perdurará até que ocorra o completo aniquilamento das classes ${ }^{186}$.

${ }^{182}$ SANTOS, Juarez Cirino dos. A Criminologia Radical. pp. 86-91.

183 Foge ao nosso propósito uma extensa abordagem das complexas e valiosas conclusões auferidas pelos autores, no que diz respeito às efetivas funções exercidas pelas teorias utilitaristas da pena. Para mais sobre o assunto, vide: SANTOS, Juarez Cirino dos. Direito Penal: Parte Geral. pp. 435-453.

184 “A pena proporcionada à culpa representa fundamentalmente a mesma forma que a reparação proporcionada ao dano. É a expressão aritmética sobretudo que caracteriza o rigor da sentença: incontáveis dias, meses etc., de privação de liberdade, multa exorbitante, perda de tantos direitos etc. A privação da liberdade com uma duração determinada através da sentença do tribunal é a forma específica pela qual o Direito Penal moderno, ou seja, burguês-capitalista, concretiza o princípio da reparação equivalente. Tal forma está inconsciente, porém profundamente ligada à representação do homem abstrato e do trabalho humano abstrato mensurável pelo tempo". PACHUKANIS, Evgeny Bronislavovich. Teoria Geral do Direito e Marxismo. p. 130.

${ }^{185}$ SANTOS, Juarez Cirino dos. Direito Penal: Parte Geral. pp. 442-451.

${ }^{186}$ PACHUKANIS, Evgeny Bronislavovich. Teoria Geral do Direito e Marxismo. p. 125. 
Apesar da solidez e atemporalidade de alguns dos argumentos marxistas, a literatura oferece ainda uma nova visão, mais técnicocriminológica e menos ideológica, da crítica à utilização da pena e do Direito Penal enquanto instrumento de controle social; aqui se destacam, como não poderia deixar de ser, as obras que contam com a participação de Zaffaroni $^{187}$. Mesmo que não utilize o termo ideologia em uma concepção depreciativa, o autor alerta para os riscos de se utilizar um ponto de vista como verdade absoluta, sem que se assuma a sua parcialidade, especialmente quanto o poder - e suas estruturas - "instrumentaliza as ideologias na parte em que lhes são úteis e as descarta quanto ao resto"188.

O Direito Penal, prossegue, deve ser compreendido como apenas um dos diversos componentes do sistema penal ${ }^{189}$, sistema que também seria mera parte do controle social institucionalizado, alheio, ainda, aos meios difusos de controle social ${ }^{190}$, citados no início do presente capítulo. A ciência em questão, portanto, teria uma importância que, embora inegável, é bem mais limitada do que pretendem afirmar outros doutrinadores, especialmente quando medido o enorme campo de controle social alheio ao seu campo de atuação ${ }^{191}$.

Estabelecido o seu modelo de pesquisa, o autor concorda que em toda sociedade existe uma estrutura de poder com segmentos controladores e controlados, exercendo o sistema penal um objetivo latente de selecionar, arbitrariamente, pessoas dos setores sociais humildes e transformá-las através da pena em criminosos para indicar aos seus pares a vigente realidade de estratificação social ${ }^{192}$. Parece-nos assumir, deste modo, que há

187 ZAFFARONI, Eugenio Raúl. Manual de Direito Penal Brasileiro; ZAFFARONI, Eugenio Raúl; BATISTA, Nilo; ALAGIA, Alejandro; SLOKAR, Alejandro. Direito Penal Brasileiro: primeiro volume - Teoria do Direito Penal.

${ }^{188}$ ZAFFARONI, Eugenio Raúl. Manual de Direito Penal Brasileiro. p. 61-66.

189 “(...) a atividade do legislador, do público, da polícia, dos juizes e funcionários e da execução penal". Ibid. p. 70.

${ }^{190}$ Ibid. p. 68.

${ }^{191}$ Ibid. p. 69.

192 Ibid. p. 77-78. 
uma relação recíproca entre criminalização seletiva dos marginalizados e fossilização social a sustentar a estrutura de poder vigente, sem utilizar, no entanto, os expedientes marxistas tradicionais.

Posteriormente, Zaffaroni ${ }^{193}$ assinala que no interior de qualquer Estado de Direito formal coexistiria antagonicamente um resquício de Estado policial, sendo o Estado mais ou menos "autoritário" segundo controle melhor ou pior essa esquizofrênica manifestação policialesca, independentemente, ressalte-se, da ideologia por ele seguida; desse fundamento, criado com a colaboração intelectual de Nilo Batista, Alagia e Slokar, nasce uma crítica negativa e agnóstica da pena ${ }^{194}$.

Diz-se uma teoria negativa por não conceder à pena qualquer dos fins pretendidos pelas teorias positivadas, conclusão a ser obtida por exclusão conforme, inclusive, depreende-se do próprio conceito de pena oferecido $^{195}$. É, ademais, agnóstica por confessar não conhecer as verdadeiras funções da pena, desconstruindo a legitimidade dos fins utilitários manifestos - as teses positivadas, estudadas no capítulo anterior mas se declarando incapaz pesquisar as funções latentes ${ }^{196}$, apesar do autor já ter aduzido que o sistema penal, enquanto gênero que engloba Direito Penal e, mais especificamente, a pena, se presta ao controle social das classes marginalizadas.

Enfim, a despeito das claras oposições ora desenhadas entre as críticas materialista dialética e negativa agnóstica, em especial no tocante às funções latentes da pena descritas por uma e relevadas pela outra,

193 “(...) em qualquer tipo de poder político institucionalizado em forma de estado, o estado de direito e o estado de polícia coexistem e lutam, como ingredientes que se combinam através de medidas diversas e de modo instável e dinâmico". ZAFFARONI, Eugenio Raúl; BATISTA, Nilo; ALAGIA, Alejandro; SLOKAR, Alejandro. Direito Penal Brasileiro: primeiro volume - Teoria do Direito Penal. p. 95.

${ }^{194}$ Assim como já mencionado na crítica materialista e dialética, não se pretende, no presente trabalho, esgotar o tema e realizar extensa abordagem das conclusões e méritos estruturais de ambas. Para uma análise mais extensa das teses de Zaffaroni, vide: Ibid. pp. 87-130.

195 “(...) coerção que impõe uma privação de direitos ou uma dor, mas não repara nem restitui, nem tampouco detém as lesões em curso ou neutraliza perigos eminentes". Ibid. p. 99.

${ }^{196}$ Ibid. p. 98-99. 
entendemos que ambas acabam por representar duas faces da mesma moeda ao comungarem da mesma premissa: enquanto a proteção de bens jurídicos atribuída ao Direito Penal revelar-se como proteção seletiva de bens jurídicos ${ }^{197}$, beneficiando os setores que na estrutura de poder tem a decisão de determinar os caminhos da tipificação ${ }^{198}$, a pretensão utilitária de que a pena constitua efetivo controle e redução da criminalidade deverá ser destituída de legitimidade.

Assim demonstram, por exemplo, que a pena privativa de liberdade, suposta aplicação da prevenção especial positiva, não conduz à diminuição da criminalidade por via da ressocialização ${ }^{199}$ e sim, paradoxalmente, à consolidação de verdadeiras carreiras $\operatorname{criminosas}^{200}$ e ao fenômeno do labelling approach $^{201}$; para adeptos da primeira crítica, manutenção da disciplina da classe trabalhadora, para a segunda, meio de estigmatização social. A prevenção geral positiva, do mesmo modo, não avigoraria a

197 BARATTA, Alessandro. Principios de Derecho Penal Mínimo. p. 301; ANDRADE, Vera Regina Pereira. A Ilusão de Segurança Jurídica: Do controle da violência à violência do controle penal. p. 291; SANTOS, Juarez Cirino dos. A Criminologia Radical. p. 35.

198 ZAFFARONI, Eugenio Raúl. Manual de Direito Penal Brasileiro. pp. 75 e 99-100; ZAFFARONI, Eugenio Raúl; BATISTA, Nilo; ALAGIA, Alejandro; SLOKAR, Alejandro. Direito Penal Brasileiro: primeiro volume - Teoria do Direito Penal. p. 96.; SANTOS, Juarez Cirino dos. A Criminologia Radical. p. 32.

${ }^{199}$ Vide item 1.1.3.1, referente à prevenção especial.

${ }^{200}$ Para Loïc Wacquant (WACQUANT, Löic. As prisões da miséria. Rio de Janeiro: Jorge Zahar, 2001. p.7): "(...) o sistema penitenciário brasileiro acumula com efeito as taras das piores jaulas do Terceiro Mundo, mas levadas a escala de Primeiro Mundo, por sua dimensão e pela indiferença estudada dos políticos e do público: entupimento estarrecedor dos estabelecimentos, o que se traduz por condições de vida e de higiene abomináveis, caracterizadas pela falta de espaço, ar, luz e alimentação (...) negação de acesso a assistência jurídica e aos cuidados elementares de saúde, cujo resultado é a dramática difusão da tuberculose e do vírus do HIV entre as classes populares; violência pandêmica entre detentos, sob forma de maus-tratos, extorsões, sovas, estupros e assassinatos em razão da superlotação superacentuada, da ausência de separação entre as diversas categorias de criminosos, da inatividade forçada (embora a lei estipule que todos os prisioneiros devam participar de programas de educação ou de formação) e das carências da supervisão". Outros autores já estudados também tem as mesmas conclusões: ZAFFARONI, Eugenio Raúl. Manual de Direito Penal Brasileiro. p. 72-76; ZAFFARONI, Eugenio Raúl; BATISTA, Nilo; ALAGIA, Alejandro; SLOKAR, Alejandro. Direito Penal Brasileiro: primeiro volume - Teoria do Direito Penal. p. 126; SANTOS, Juarez Cirino dos. A Criminologia Radical. p. 58; BARATTA, Alessandro. Principios de Derecho Penal Mínimo. p. 302; ANDRADE, Vera Regina Pereira. A Ilusão de Segurança Jurídica: Do controle da violência à violência do controle penal. p. 291. FOUCAULT, Michel. Vigiar e Punir. p. 230.

${ }^{201}$ BARATTA, Alessandro. Criminología Crítica y Crítica del Derecho Penal: Introducción a la sociologia jurídico-penal. p. 83. 
mentalidade ético-social da comunidade ou a validade da norma perante aquela $^{202}$, possuindo sim valor simbólico, representativo de produção de consenso $^{203}$; para adeptos da primeira, manutenção da ideologia capitalista, para a segunda, reforço dos sistemas social desigual e penal seletivo.

Siga-se uma ou outra vertente da criminologia crítica, há de se concordar que existe uma utilização latente do Direito Penal como instrumento de controle social e conservação do status quo, quer constituindo o monopólio da pena um pilar de “"corpos dóceis",204, da "disciplina",205 a ensejar a manutenção da dominação da burguesia sobre a massa operária, quer causando incidentalmente uma estratificação social enquanto parte de um sistema penal que seleciona pessoas das classes mais afastadas dos centro de poder.

Creiamos ou não, portanto, na necessidade de discriminação das funções da pena, estas apenas refletiriam a realidade de controle social demonstrada pela criminologia crítica em geral, negando sobremaneira validade à legitimidade exercida pelo discurso jurídico ordinário; é, de fato, uma legitimação. Em síntese: as funções da pena nada mais são que o espelho distorcido do fracasso dos seus fins.

Não por acaso que Ferrajoli ${ }^{206}$, refletindo sobre os custos e objetivos do Direito Penal, classifica a legitimação do soberano poder de punir do Estado como a "manifestação mais violenta, mais duramente lesiva aos interesses fundamentais do cidadão e, em maior escala, mais suscetível de

\footnotetext{
${ }^{202}$ Vide item 1.1.3.2, referente à prevenção geral

203 ZAFFARONI, Eugenio Raúl. Manual de Direito Penal Brasileiro. p. 107; ZAFFARONI, Eugenio Raúl; BATISTA, Nilo; ALAGIA, Alejandro; SLOKAR, Alejandro. Direito Penal Brasileiro: primeiro volume - Teoria do Direito Penal. p. 121; SANTOS, Juarez Cirino dos. Direito Penal: Parte Geral. p. 450; BARATTA, Alessandro. Principios de Derecho Penal Mínimo. p. 313; BARATTA, Alessandro. Criminología Crítica y Crítica del Derecho Penal: Introducción a la sociologia jurídico-penal. p. 218.

${ }^{204}$ FOUCAULT, Michel. Vigiar e Punir. p. 119.

205 Ibid. p. 177.

${ }^{206}$ FERRAJOLI, Luigi. Direito e Razão: Teoria do Garantismo Penal. p. 196.
} 
degenerar-se em arbítrio". É, infelizmente, uma constatação cada vez mais verdadeira. 


\title{
Capítulo 3 - Demanda relegitimadora e movimentos de expansionismo penal
}

\begin{abstract}
"Moderno, de tendencia político-criminal"207, frase que resumiria o Código Penal brasileiro segundo o renomado jurista argentino Carlos Fontán Balestra, durante análise de direito comparado realizada anteriormente à reforma da parte geral do Código, mas que muito bem poderia ter sido - e constantemente é - dita atualmente. Define-se política criminal $^{208}$ como uma série de atos políticos de transformação social, institucional e desempenhados na busca por uma isonomia não meramente formal, que, passando por salários dignos, saúde e moradia e escolarização, gerariam uma diminuição da população que se vê obrigada a cometer delitos. Política penal ${ }^{209}$, por sua vez, compreende a resposta à questão criminal que se inclui no âmbito da punição estatal, tipificação, aplicação da lei e execução da pena.
\end{abstract}

A "política criminal" brasileira, conforme visto no estudo da legitimidade prestada pela teoria jurídica da pena, é definida pelas teorias utilitárias unificadoras positivadas no código repressor: a necessidade de fixação da pena de acordo com a culpabilidade e de modo suficiente para a reprovação e prevenção do crime ${ }^{210}$. O que se vende como política criminal do Estado brasileiro é, na verdade, mera política penal negativa instituída pelo Código Penal $^{211}$, única resposta oficial à questão criminal. O Brasil se vale dos fins repressores e utilitários da pena, legalmente inclusos legislação penal, para legitimar mediante a teoria jurídica da pena o

\footnotetext{
${ }^{207}$ BALESTRA, Carlos Fontán. Tratado de Derecho Penal: Tomo I. p. 152.

${ }^{208}$ BARATTA, Alessandro. Criminología Crítica y Crítica del Derecho Penal: Introducción a la sociologia jurídico-penal. p. 213.

${ }^{209}$ Ibid. p. 212.

${ }^{210}$ Tal previsão alude, lembramos, aos três fatos naturalísticos que constituem o cerne da ciência penal: prevenção geral negativa mediante tipificação, pelo Estado, dos atos tidos como criminosos; retribuição e prevenção geral positiva mediante aplicação da pena ao eventual autor de um crime, após juízo de valor oficial do Estado; e prevenção especial positiva mediante execução, pelo Estado, da medida repressiva previamente cominada ao autor considerado culpado.

${ }^{211}$ SANTOS, Juarez Cirino dos. Direito Penal: Parte Geral. p. 419.
} 
objetivo manifesto do Direito Penal de proteger bens jurídicos e, em uma maior expressão, garantir a "convivência social" que define as relações heterogêneas de uma sociedade.

Enfim, finalidades positivadas, utilizadas e negligenciadas, para o bem e também para o mal. Não se pretendera desenhar até aqui uma trajetória de simples fracasso da proteção de bens via redução da criminalidade, mas sim de relação conflitual e unitária entre essa e o sucesso do latente projeto de controle social via pretensa redução da criminalidade. Desta paradoxal unidade entre objetivos manifestos e latentes, fins e funções da pena, é possível compreender porque conviveram, nos últimos quinze a vinte anos, algumas aplicações práticas da negação à legitimação defendida pela criminologia crítica e uma subsistente, porém, severa demanda de relegitimação da intervenção estatal. Por "relegitimação" queremos dizer que, sem embargo à provada falsificação dos consectários utilitaristas da prevenção geral e especial, o ius puniendi segue encontrando neles o fundamento de sua aplicação ${ }^{212} \mathrm{e}$, pior, de uma expansão de sua aplicação.

De um lado, temos convivido com determinados discursos que demandam a minimização da violência mediante fortalecimento das garantias individuais, ou de sua substituição por políticas alternativas de resolução de conflitos, como a justiça restaurativa ${ }^{213}$. Outros exemplos da tendência de negar legitimação ao Direito Penal e à pena são a reforma de 1984, a Lei dos Juizados Especiais e, mais recentemente, a atualização dos trechos do Código de Processo Penal referentes à prisão preventiva e à

\footnotetext{
${ }^{212}$ ANDRADE, Vera Regina Pereira. A Ilusão de Segurança Jurídica: Do controle da violência à violência do controle penal. p. 294-295.

213 “(...) processo de soberania e democracia participativa numa justiça penal e social inclusa, perante o diálogo das partes envolvidas no conflito e comunidade, para melhor solução que o caso requer, analisando-o em suas peculiaridades e resolvendo-o em acordo com a vítima, o desviante e a comunidade, numa concepção de direitos humanos extensíveis a todos, em respeito ao multiculturalismo e à autodeterminação". SALIBA, Marcelo Gonçalves. Justiça Restaurativa $e$ Paradigma Punitivo. p. 148.
} 
fiança, que antecedem e refletem alguns dos poucos pontos positivos do novo diploma ainda em discussão no Congresso.

Paralelamente, vemos com receio um ameaçador movimento relegitimador baseado, principalmente, no expansionismo penal que caracteriza a "política criminal" praticada nos últimos anos. Confiramos a lição de Manuel Cancio Meliá:

"Las características principales de la política criminal practicada en los últimos años pueden resumirse en el concepto de la 'expansión' del Derecho penal. En efecto, en el momento actual puede convenirse que el fenómeno más destacado en la evolución actual de las legislaciones penales del 'mundo occidental' está en la aparición de múltiples nuevas figuras, a veces incluso de enteros nuevos sectores de regulación, acompañada de una actividad de reforma de tipos penales ya existentes realizada a un ritmo muy superior al de épocas anteriores, 214 .

Assim, verifica-se um movimento de praticamente toda a sociedade pela utilização do Direito Penal em diversificadas questões que vão desde a chamada tradicional criminalidade violenta, como as organizações do tráfico de drogas, até a corrupção política, administrativa, econômica e financeira $^{215}$. São demandas que, ademais, englobam tanto o incremento da retribuição e prevenção geral negativa, através do aumento de penas, e maximização do aparelho policial ${ }^{216}$, quanto o apelo à prevenção especial negativa, através de regimes disciplinares diferenciados, prisões perpétuas e penas de morte, essas duas últimas eventualmente exploradas em eleições.

Necessária a análise, portanto, de dois fenômenos que nos parecem representativos da atual realidade expansionista brasileira: o chamado “Direito Penal simbólico", que, veremos a seguir, é entendido em sua perspectiva mais extensa por autores adeptos da criminologia crítica; e o ressurgir do punitivismo através da chamada "esquerda punitiva", termo

\footnotetext{
214 MELIÁ, Manoel Cancio; JAKOBS, Günther. Derecho Penal del Enemigo. Madrid: Civitas, 2003. pp. 62-64.

${ }^{215}$ ANDRADE, Vera Regina Pereira. A Ilusão de Segurança Jurídica: Do controle da violência à violência do controle penal. p. 296.

${ }^{216}$ Sobre o assunto: SULOCKI, Victoria-Amália de. Segurança Pública e Democracia: Aspectos Constitucionais das Políticas Públicas de Segurança.
} 
cunhado por Maria Lúcia Karam ${ }^{217}$ para descrever mudanças nada salutares na tradicional equação "direita-penalização" e "esquerda-despenalização". Assevere-se, desde já, que não raro ambos se apresentam de forma paradoxalmente conjunta, interligada.

\section{1 - Direito Penal: simbólico}

Ante a obra construída no primeiro capítulo e desconstruída no segundo, impôs-se a constatação, por parte da criminologia crítica em geral, de que a dissimulação entre objetivos declarados e fins e objetivos manifestos e funções caracteriza o Direito Penal como essencialmente simbólico $^{218}$. Há, portanto, uma dissensão entre o conteúdo programático e a prática penal, entre os fins utilitários que legitimam o objetivo de exclusiva proteção de bens jurídicos e a utilização, por parte das classes dominantes, da pena exclusivamente estatal e daqueles fins de prevenção especial e prevenção geral como funções de transmissão de fidelidade ao Direito para os demais membros da sociedade, objetivando, dissimuladamente, a manutenção do status $q u o^{219}$ de controle social vigente.

Simplesmente bradar a inerência simbólica do Direito Penal contemporâneo, no entanto, não pode servir de escusa para que se ignore outras facetas dessa terminologia, extremamente numerosas e, infelizmente, de maior atualidade e urgência prática: o simbolismo originário da ciência possibilitara a geração de inúmeras legislações que padecem do mesmo

217 KARAM, Maria Lúcia. Expansão do poder punitivo e violação de direitos fundamentais. Disponível em <http://www.mundojuridico.adv.br>. Acesso em 10 de maio de 2011.

218 ZAFFARONI, Eugenio Raúl. Manual de Direito Penal Brasileiro. p. 78; BARATTA, Alessandro. Criminología Crítica y Crítica del Derecho Penal: Introducción a la sociologia jurídico-penal. pp. 217-219; BARATTA, Alessandro. Principios de Derecho Penal Mínimo. p. 301; SANTOS, Juarez Cirino dos. Direito Penal:Parte Geral. p. 451; ANDRADE, Vera Regina Pereira. A Ilusão de Segurança Jurídica: Do controle da violência à violência do controle penal. pp. 292-293.

${ }^{219}$ SULOCKI, Victoria-Amália de. Segurança Pública e Democracia: Aspectos Constitucionais das Políticas Públicas de Segurança. p. 197. 
sintoma, a orientação a uma manifesta consequência ${ }^{220}$ através de fins utilitários, somente com objetivos e dissimulações distintas. Enquanto o Direito Penal visa proteger bens jurídicos e consolida um sistema desigual perante a comunidade, a manutenção da tipificação do aborto no formalmente laico Brasil, por exemplo, só tem como uma das suas metas valorar o bem jurídico vida.

Uma observação mais atenta evidencia que o que é válido para o Direito Penal é, proporcionalmente, para grande parte dos fins da pena orientados de forma utilitária, e quanto mais exigentes se formulem os estes fins ressocializadores, ameaçadores ou, principalmente, reforçadores da norma, mais claramente evidenciam o seu conteúdo simbólico: perseguem transmitir, cognitiva e emotivamente, com a intervenção utilitarista do Direito Penal uma mensagem de vida de fidelidade ao Direito ${ }^{221}$ e ao status quo.

As próprias abordagens aos termos "simbólico" e "legislação simbólica" possuem enfoques variados ${ }^{222}$ e que não foram suficientemente precisados pela doutrina, graças, em parte, à constatação de que todas as leis, especialmente as penais, "tienen un impacto simbólico más o menos grande por deber operar sobre la formación de la consciencia de la población" ${ }^{, 223}$, não sendo inadmissíveis de modo geral. Zaffaroni, inclusive, afirma que a pena "sempre cumprirá uma função simbólica", sendo irracional quando "só cumpre esta última"224, seguindo a premissa de Meliá, para quem “es incorrecto el discurso del 'Derecho penal simbólico' como fenómeno extraño al Derecho penal" ${ }^{225}$. Com isto em mente, razoável que se entenda o porquê da criminalização do já citado aborto em países

\footnotetext{
${ }^{220}$ HASSEMER, Winfried. Derecho Penal Simbólico y Protección de Bienes Jurídicos. p. 30.

${ }^{221}$ Ibid. p. 27.

${ }^{222}$ RIPOLLÉS, José Luis Diez. El Derecho Penal Simbólico y los Efectos de la Pena. p. 11.

${ }^{223}$ ROXIN, Claus. Derecho Penal: Parte General. p. 59.

${ }^{224}$ ZAFFARONI, Eugenio Raúl. Manual de Direito Penal Brasileiro. pp. 107-108.

${ }^{225}$ MELIÁ, Manoel Cancio; JAKOBS, Günther. Derecho Penal del Enemigo. p. 67.
} 
constitucionalmente seculares, reflexo dos valores religiosos que definem a convivência pacífica naquele estilo de vida - sem embargo aos eventuais, e aqui irrelevantes, efeitos criticamente simbólicos ou desumanos que venha a ter.

Buscássemos um denominador comum a todas as definições do simbólico enquanto merecedor de crítica, teríamos que recorrer à impecável lição de Winfried Hassemer:

"Existe un acuerdo global respecto de la dirección en la cual se busca el fenómeno de Derecho simbólico: se trata de una oposición entre 'realidad' y 'apariencia', entre 'manifiesto' y 'latente', entre lo 'verdadeiramente querido' $y$ lo 'otramente aplicado'; y se trata siempre de los efectos reales de las leyes penales. Simbólico se asocia con 'engaño', tanto en sentido transitivo como reflexivo" 226 .

Finaliza o autor:

“'Simbólico' en sentido crítico es por consiguiente um Derecho penal en el cual las funciones latentes predominen sobre las manifiestas: del cual puede esperarse que se realice através de la norma y su aplicación otros objectivos que los descritos en la norma. Com ello se entiende - como ya expresa la determinación del concepto - por 'funciones manifiestas' (...) la protección de bien jurídico previsto en la norma. Las 'funciones latentes' son múltiples (...),227.

Ressalte-se que aqui realizamos mero resumo basal do fenômeno, sem prejuízo de análises mais brandas, como a de José Diez Ripollés ${ }^{228}$, ou dos já mencionados exames extremos, focados no simbolismo penal originário, oriundos de criminalistas radicais como Juarez Cirino ${ }^{229}$.

${ }^{226}$ HASSEMER, Winfried. Derecho Penal Simbólico y Protección de Bienes Jurídicos. p. 28.

${ }^{227}$ Ibid. p. 30.

228 "A mi juicio, el fenómeno del derecho penal simbólico no se puede entender como un problema de desajuste entre los efectos que se pretenden (fin) o se creen (función) conseguir, y los que realmente se pretenden u obtienen. (...) Hasta el punto de que si una intervención penal produce efectos que previenen comportamientos lesivos de bienes jurídicos, no se la descalificará como 'simbólica' por más que ese efecto o efectos producidos no se hubieran querido o previsto. El énfasis en el engaño o en la ficción supone, en el mejor de los casos, fijarse en lo adjetivo y no en lo sustantivo". RIPOLLÉS, José Luis Diez. El Derecho Penal Simbólico y los Efectos de la Pena. p. 12.

229 "Sabe-se que o Direito Penal realiza funções instrumentais de efetiva aplicação prática e funções simbólicas de projeção de imagens na psicologia popular, mas o segmento legal conhecido como Direito Penal simbólico, caracterizado pela criminalização do risco em áreas cada vez mais distantes do bem jurídico (...) não tem função instrumental, apenas função simbólica de legitimação do poder político". SANTOS, Juarez Cirino dos. Direito Penal:Parte Geral. p. 449. 
No Brasil, é costume que se vincule os efeitos simbólicos penais às chamadas leis de $\operatorname{crise}^{230}$, de emergência ${ }^{231}$ ou apaziguadoras ${ }^{232}$, aquelas geradas pelo legislador com o objetivo de tranquilizar a opinião pública que clama por uma solução repressiva para um determinado comportamento, não o prevenindo em concreto. Quer-se, na verdade, "suscitar la impressión de que 'se hace algo,"233 na comunidade, simbolizando um legislador ou membros do poder público atentos às demandas sociais ${ }^{234}$. Não buscam, portanto, "efectos protectores concretos", mas sim "autoafirmación de grupos, $^{, 235}$.

Trata-se de uma prática recorrente na sociedade pós-moderna globalizada, em que os veículos de "mass media",236 pautam-se por agendas editoriais e financeiras alheias ao conhecimento da população por elas atingida, crente da idoneidade das informações recebidas. Eventuais momentos de crise são veementemente tomados de assalto pela imprensa através de verdadeiras campanhas de "alarma social",237, as quais perduram até que o poder público acene com alguma solução, quase sempre simbólica e ausente de intenções concretas, mesmo que venha a acarretar mudanças. Cite-se, por exemplo, a lei 11.340/06, cognominada "Maria da Penha"238

\footnotetext{
${ }^{230}$ HASSEMER, Winfried. Derecho Penal Simbólico y Protección de Bienes Jurídicos. p. 26.

${ }^{231}$ ZAFFARONI, Eugenio Raúl. La Creciente Legislación Penal y los Discursos de Emergencia. In: Vários Autores, Teorías Actuales en el Derecho Penal. Buenos Aires: Editorial Ad-Hoc, 1998. pp. 613-620. O artigo é focado na problemática das leis de emergência, apesar de não as vincular às funções simbólicas da pena.

${ }^{232}$ RIPOLLÉS, José Luis Diez. El Derecho Penal Simbólico y los Efectos de la Pena. p. 15.

${ }^{233}$ ROXIN, Claus. Derecho Penal: Parte General. p. 59.

234 Apesar de sua visão relativamente mais afeita aos efeitos simbólicos da pena, José Diez (RIPOLLÉS, José Luis Diez. El Derecho Penal Simbólico y los Efectos de la Pena. p. 17) critica esta modalidade: "Especialmente sospechosas y necesitadas de verificación serán aquellas intervenciones penales que creen o incrementen de forma patente una imagen positiva del legislador o del resto de los operadores penales, o las que sean consecutivas a campañas mediáticas o de grupos de presión sucedidas poco tiempo antes sobre el mismo objeto de la intervención penal, o que causen la impresión de que persiguen objetivos distintos a los declarados".

${ }^{235}$ ROXIN, Claus. Derecho Penal: Parte General. p. 59.

${ }^{236}$ BARATTA, Alessandro. Criminología Crítica y Crítica del Derecho Penal: Introducción a la sociologia jurídico-penal. p. 218.

${ }^{237}$ Ibid. p. 218.

${ }^{238}$ Lei de violência doméstica e familiar contra a mulher. O caso já fora abordado pela doutrina: ANJOS, Fernando Vernice dos. Direito Penal Simbólico e Lei de Combate à Violência Doméstica
} 
em homenagem a uma das dezenas de mulheres que anualmente sofrem tentativas de homicídio realizadas por seus próprios cônjuges; ainda que se aleguem os ambíguos sucessos das medidas que recrudesceram o tratamento penal a casos semelhantes, ainda mais satisfatórias seriam mudanças extrapenais e culturais que os prevenissem a longo prazo, como uma maior igualdade no mercado de trabalho.

Outros casos ainda mais danosos e recentes são a série de eventos que levaram à cinematográfica e militarizada ocupação do complexo de favelas do Alemão, no Rio de Janeiro ${ }^{239}$ (que também é exemplo do fenômeno a ser abordado a seguir), bem como a demagoga tentativa de revisão do estatuto do desarmamento, elaborado com base nos resultados do plebiscito de 2005, em virtude dos homicídios ocorridos em uma escola de Realengo $^{240}$; ambos, há de se ressaltar, amplamente apoiados pela população e por partidos interessados nos louros - e votos - por ter "hecho algo". É a perpetuação do entendimento de que o expansionismo penal, através de movimentos de "ley y orden" 241 , se presta a mostrar um comprometimento com a diminuição da criminalidade a custos economicamente menores do que efetivamente resolver as questões sociais de fundo ${ }^{242}$.

e Familiar Contra a Mulher. Disponível em <www.ibccrim.com.br>. Acesso em 15 de maio de 2011.

${ }^{239}$ Polícia e Exército iniciam invasão no Complexo do Alemão. Disponível em $<\mathrm{http}: / /$ www.estadao.com.br/noticias/nacional,policia-e-exercito-iniciam-invasao-no-complexodo-alemao,646417,0.htm>. Acesso em 20 de maio de 2011.

240 Atirador invade escola e mata alunos no Rio; saiba como foi. Disponível em http://www1.folha.uol.com.br/cotidiano/899801-atirador-invade-escola-e-mata-alunos-no-riosaiba-como-foi.shtml>. Acesso em 20 de maio de 2011.

${ }^{241}$ BARATTA, Alessandro. Criminología Crítica y Crítica del Derecho Penal: Introducción a la sociologia jurídico-penal. p. 218.

242 "La producción simbólica de normas penales a las que estamos acostumbrados en nuestro país por la cual se aumentan indiscriminadamente las escalas, están justificadas y son válidas más allá de su eficacia práctica, porque en términos de costos sociales implican un esfuerzo económico mucho menor de lo que serían encarar las soluciones plausibles: atacar las causas sociales del fenómeno, mejorar la calidad del servicio de justicia, reforzar el equipamiento y la retribución de las agencias pol iciales". PARMA, Carlos. Reexaminando el Derecho Penal. p. 5. Disponível em <www.4shared.com>. Acesso em 15 de maio de 2011. 
A despeito de serem mais comuns que outras modalidades, as leis simbólicas de crise não são exclusivas na prática legislativa brasileira. Sem a pretensão de delinearmos todos os exemplos existentes, também encontramos $^{243}$ : leis autoritárias, que demonstram a capacidade coativa do Estado, como, por exemplo, a Lei dos Crimes Hediondos; leis modificadoras, que buscam mudar atitudes ante certos problemas sociais, como os crimes relativos ao meio ambiente; leis declarativas, que visam implementar ou manter determinados valores no seio da sociedade, como a criminalização do aborto, do uso da cannabis $^{244}$ e a pendente equiparação da homofobia ao racismo. Enfim, são apenas exemplos isolados que não demonstram a amplitude da situação.

Limitações à parte, tais casos denunciam com sucesso a dificuldade de se constituir a teoria do bem jurídico como meio eficaz de restrição à atividade persecutória estatal. Basta que assistamos à fartura de delitos cujos bens jurídicos não somente são "universais", alegadamente protetivos de toda a comunidade, mas também concebidos de forma vaga de forma a causar oportunas dissensões doutrinárias. Outra prática hoje comum é criminalização do risco em áreas cada vez mais distantes do bem jurídico, como os tipos de perigo abstrato, aqueles que presumem o perigo sem que haja a necessidade da sua produção real ${ }^{245}$. Na lição de Meliá:

“(...) la actividad legislativa en materia penal desarrollada a lo largo de las dos últimas décadas en los países de nuestro entorno ha colocado alrededor del elenco nuclear de normas penales un conjunto de tipos penales que, vistos desde la perspectiva de los bienes jurídicos clásicos, constituyen supuestos de ‘criminalización' en el estadio previo a lesiones de bienes jurídicos",246.

\footnotetext{
${ }^{243}$ RIPOLLÉS, José Luis Diez. El Derecho Penal Simbólico y los Efectos de la Pena. pp. 13-16.

${ }^{244}$ No caso, há também o interesse de países estrangeiros nessa manutenção.

245 SANTOS, Juarez Cirino dos. Direito Penal:Parte Geral. p. 108.

${ }^{246}$ MELIÁ, Manoel Cancio; JAKOBS, Günther. Derecho Penal del Enemigo. p. 64.
} 
Complementa ainda Hassemer, aduzindo que o nicho destes atos normativos é, essencialmente, o chamado direito penal econômico ${ }^{247}$ :

"Ya en una primera aproximación vemos que las nuevas leyes en el ámbito de nuestro Derecho penal material (parte especial y leyes penales especiales) no tienen como objeto de protección sólo bienes jurídicos universales sino asi mismo que estos bienes jurídicos están formulados de forma especialmente vaga. Ámbitos específicos de promulgación de leyes son fundamentalmente el derecho penal económico, los impuestos, medio ambientea, acumulación de datos, terrorismo, drogas, exportación de materias peligrosas. Los bienes jurídicos comprendidos en este ámbito son tan generales que no dejan ningun deseo sin satisfacer, ${ }^{, 48}$.

A já tantas vezes mencionada diminuição ou prevenção da criminalidade deixa de ser a tarefa dos fins utilitários da pena, trata-se, agora, de ladear a proteção dos interesses pessoais, do meio ambiente (politicamente), da diplomacia externa e dos impostos. Parece-nos, de fato, não interessar aos objetivos controladores latentes que sejamos capazes de criar este meio termo sistemático entre o abandono dos bens jurídico e o penalismo global, situação em que o Direito Penal deixaria de ser cômodo às ambições políticas de quem quer que as tenha, direita ou esquerda.

\section{2 - O ressurgir do punitivismo através da esquerda punitiva}

Desde o advento da modernidade que a pena, ou o "poder de uma comunidade política qualquer de exercitar uma violência programada sobre um dos seus membros" 249 , constitui "el medio coactivo más contundente com que cuenta el Estado" ${ }^{250}$. O Estado de Direito tornou-se o detentor exclusivo do poder punitivo, o que o possibilitara privar de liberdade ou

\footnotetext{
${ }^{247}$ No mesmo sentido, Maria Lúcia Karam (KARAM, Maria Lúcia. Expansão do poder punitivo $e$ violação de direitos fundamentais. p. 7): "A desautorizada tendência de formulação de tipos genéricos ou vazios é reforçada a partir do desenvolvimento do direito penal econômico, sob o pretexto de que a maior complexidade de condutas e o caráter macro-social dos bens jurídicos tutelados o diferenciariam do direito penal dito ordinário, por isso ali devendo se admitir uma certa flexibilidade na definição das condutas típicas e em outros aspectos do processo de criminalização".

${ }^{248}$ HASSEMER, Winfried. Derecho Penal Simbólico y Protección de Bienes Jurídicos. p. 10.

${ }^{249}$ FERRAJOLI, Luigi. Direito e Razão: Teoria do Garantismo Penal. p. 230.

${ }^{250}$ MIR PUIG, Santiago. El Derecho Penal en el Estado Social y Democrático. p. 115.
} 
vida o membro que violar algum dos bens jurídicos eleitos relevantes e, reflexamente, auxiliar no projeto liberal-modernista de segregação, má distribuição de rendas, injustiça social e inacessibilidade às demandas sociais.

Visando uma superação dessa precária prática, concebeu-se no decorrer do século XX uma outra modalidade de Estado chamada Estado Social de Direito, que teria o propósito de agir como motor ativo na vida da sociedade, modificando efetivamente as relações sociais, sem, contudo, abandonar os consectários do modo de produção liberal vigente - o chamado Welfare State. Do Estado Liberal dito "imparcial" se passa a um Estado Social "intervencionista" que, não implicando necessariamente em uma concepção autoritária, fora incapaz de assegurar a autêntica participação do povo no processo político ${ }^{251}$. Até a denominação "Social”, aliás, fora objeto de críticas na medida em que comporta enorme gama de interpretações, dada a sua utilização da Alemanha de Hitler à Itália de Mussollini, passando pelo "Estado Novo" de Getúlio Vargas, estabelecido pela constituição de $1937 .^{252}$

Sofremos, então, tenebrosos tempos até que a Constituição da República Federativa de 1988 viesse a instituir formalmente o Estado Democrático de Direito brasileiro no caput do seu art. $1^{\circ}$. José Afonso ressalta que a adição do "Democrático" visa a tentar realizar o princípio democrático como garantia geral dos direitos fundamentais da pessoa humana, questão nem sempre bem sucedida no tradicional "de Direito", quer como Liberal ou Social ${ }^{253}$. No que diz respeito aos seus caracteres básicos, o Estado Democrático de Direito defende, ao menos em tese, "a observância do princípio da legalidade e a supremacia da lei, como garantia

\footnotetext{
${ }^{251}$ SILVA, José Afonso da. Curso de Direito Constitucional Positivo. p. 118.

${ }^{252}$ Ibid. p. 116.

${ }^{253}$ Ibid. p. 117.
} 
máxima de segurança jurídica para todos os cidadãos", exercendo também "uma função transformadora, influindo na realidade social"254.

Há uma relativa síntese de determinadas peculiaridades dos Estados Liberal e Social, tentativa de conciliar a orientação do segundo pela mudança nas relações sociais a serviço da isonomia material ${ }^{255}$ com os limites formais do primeiro. Seguindo essa nova lógica definidora do Estado, a constituição deveria não apenas prever a isonomia formal, mas sim desmistificar a sua liberal vocação de mecanismo de manutenção da injustiça social e das desigualdades.

Passados vinte anos da vigência constitucional, pesquisas ${ }^{256}$ mostram que temos obtido um tímido sucesso na meta maior de diminuição da estratificação característica da nossa sociedade de mercado, como resultado, em especial, de adotados e eventualmente ampliados projetos sociais de transferência de renda. Até mesmo as estatísticas de desemprego ${ }^{257}$ divulgadas pelo governo federal demonstram um otimismo com os rumos da economia. Trata-se de uma evolução que, no entanto, não evidencia uma plena superação dos desequilíbrios sociais ${ }^{258}$; contrariamente, compartilhamos a certeza de Victoria de Sulocki ao afirmar que o Direito continua a ser "meio de mascarar as desigualdades existentes através da afirmação de igualdade de todos perante a lei" ${ }^{\prime 259}$.

\footnotetext{
${ }^{254}$ ALVES, Cléber. Acesso à Justiça, Estado de Direito e Consolidação Democrática na América Latina: o Papel da Defensoria Pública. In: ALVES, Cléber. Acesso à justiça em preto e branco: retratos institucionais da defensoria publica. Rio de Janeiro: Lumen Juris, 2004. p. 112.

${ }^{255}$ MIR PUIG, Santiago. El Derecho Penal en el Estado Social y Democrático. p. 33.

256 IPEA analisa pobreza e miséria por regiões e estados. Disponível em $<$ http://www.ipea.gov.br/portal/index.php?option=com_content\&view=article\&id=1571:ipeaanalisa-pobreza-e-miseria-por-regioes-e-estados\&catid=4:presidencia\&Itemid=2>. Acesso em 25 de maio de 2011.

257 Taxa de desemprego é a menor para abril desde 2002. Disponível em $<$ http://globonews.globo.com/videos/v/taxa-de-desemprego-e-a-menor-para-abril-desde-

2002/1519204/>. Acesso em 30 de maio de 2011.

${ }^{258}$ KARAM, Maria Lúcia. Expansão do poder punitivo e violação de direitos fundamentais. p. 1.

${ }^{259}$ SULOCKI, Victoria-Amália de. Segurança Pública e Democracia: Aspectos Constitucionais das Políticas Públicas de Segurança. p. 161.
} 
Apenas em campo teórico-legislativo é possível que criemos figuras imaginárias como as dos cidadãos, as classifiquemos como iguais, e determinemos que o tratamento oferecido pelo Estado seja semelhante a todos, peões e fazendeiros, favelados e moradores "do asfalto",260. Por consequência, apenas em campo teórico-legislativo podemos esperar que a aplicação da legislação criminal seja semelhante, paritária, que tenhamos um percentual relativo de dominantes e dominados inserido no sistema prisional, entidades de exercício da utilitária prevenção especial positiva. A dissensão entre programação legislativa e realidade, inclusive, já fora suficientemente exposta no segundo capítulo, onde tratamos da contribuição do papel do Direito Penal no controle social de marginalizados.

Como curiosa resposta a esta distorção entre norma e fato, acreditase, veja só, que uma ainda maior intervenção do Direito Penal servirá de instrumento para a transformação social ou de emancipação dos oprimidos, "solução" aplicada pelos setores políticos de esquerda, aqueles usualmente atentos às desigualdades que definem o nosso Estado. Há uma brusca mudança no tradicional papel "izquierda política-demandas de descriminalización/derecha política-demandas de criminalización" ${ }^{261}$, ao ponto em a única diferença entre preocupações, discursos e práticas é o foco da truculência, dominantes ou dominados, "sinalizando que, pelo menos nesse campo, a contraposição entre direita e esquerda perdeu mesmo sua razão de ser"262. Não estamos afirmando que a direita deixa de ser afeita à criminalização exacerbada, mas que, paulatinamente, a esquerda se iguala àquela nesse quesito.

Reforça-se ainda, no campo do discurso legitimador do Direito Penal, a já tantas vezes mencionada deturpação da "política criminal" brasileira, que, agora, não satisfeita com os desiguais resultados obtidos

\footnotetext{
${ }^{260}$ Ibid. pp. 161-164.

${ }^{261}$ MELIÁ, Manoel Cancio; JAKOBS, Günther. Derecho Penal del Enemigo. p. 70.

${ }^{262}$ KARAM, Maria Lúcia. Expansão do poder punitivo e violação de direitos fundamentais. p. 2.
} 
pelo utilitarismo liberal, encobre seus desígnios punitivos sob o pretexto de renovar a efetivação da Constituição do Estado Democrático de Direito. Esta "esquerda punitiva", como cunhada por Maria Lúcia Karam²63, contraditoriamente solapa as bases do próprio Estado ${ }^{264}$ ao tentar dar feições positivas a um instrumento que ela mesmo considera, e que aqui concordamos ser, negativo. Existem até aqueles ${ }^{265}$ que, cientes da hipocrisia que perpassa tal pretensão, tão-somente contentam-se em ver cruel, porém, igualitário tratamento penal.

"Os fins justificam os meios", diriam uns, ignorando que o fracasso dessa finalidade está na própria concepção da pena enquanto instrumento de controle social; na realidade, como já mostrou Zaffaroni ${ }^{266}$, a retirada do manto de cobertura de quem domina só se dá em raros casos onde conflitos entre setores hegemônicos permitam o sacrifício de alguém. Ao almejarem, então, unicamente criar um tratamento penal diferenciado a crimes típicos dos setores dominantes, em permuta de uma nem sempre presente tolerância aos dominados, acabam por legitimar um rigor que invariavelmente também se aplicará às camadas mais oprimidas.

Presenciamos a edição de leis de Direito Penal econômico ou secundário em geral que, sem prejuízo de também constituírem o fenômeno do Direito Penal simbólico, desvinculam do reconhecimento de bem jurídico digno de tutela a necessidade de que constitua direitos individuais concretos, bem como criam tipos de perigo abstrato baseados no mero risco, antecipando o momento criminalizador. É constante o desrespeito aos princípios basilares da teoria do bem jurídico estudados no primeiro capítulo - legalidade, ofensividade, insignificância, proporcionalidade,

\footnotetext{
${ }^{263}$ Ibid. p. 5.

${ }^{264}$ Ibid. pp. 4-5.

265 MATTOS, Virgílio de. Esquerda Punitiva, Punição e Opção Ideológica. Disponível em <http://carlosmagalhaes.com.br/2011/04/11/esquerda-punitiva-punicao-e-opcao-ideologica/>. Acesso em 17 de abril de 2011.

${ }^{266}$ ZAFFARONI, Eugenio Raúl. Manual de Direito Penal Brasileiro. p. 78.
} 
ultima ratio e fragmentariedade. A escalada continuará até o momento em que não for mais visível a linha que separa o Estado de Direito do Estado policial $^{267}$ que nele vive, e, enquanto se passa a admitir um processo penal com ares inquisitoriais, pautado por abortos legislativos como a Lei 9034/95 ${ }^{268}$, a seleção dos indivíduos que, processados e condenados, serão demonizados como "outro", continua a se fazer de forma majoritária entre os marginalizados ${ }^{269}$, e de forma ainda mais grave, apesar da eleição de alguns poucos das classes dominantes para esse papel.

Os eleitos, aliás, aprendem da pior maneira possível o que a sociedade encontrara para substituir a execução pública como forma de repúdio ao "outro". A punição exemplar deixa de ser tarefa do fogo, das cordas, pedras e guilhotinas: agora, aparentemente, ninguém sabe o que é ser punido até ser surpreendido, no despertar do dia, pela polícia judiciária cumprindo mandados de busca e apreensão em sua residência, devidamente acompanhada de um ou outro veículo de imprensa ansioso por imagens do “outro" em suas roupas de baixo, prontas a alimentar a "alarma social". Ou então tomar ciência através dos mesmos veículos que será "intimado a comparecer em sede policial" para prestar esclarecimentos sobre tais eventos. Quando, eventualmente, é deferida uma prisão cautelar, ergue-se delegado, magistrado e procurador à categoria de defensores dos oprimidos e instrumentos de mudança social, tenham ou não ignorado diversas garantias constitucionais do "outro"; talvez se tornem desembargadores ou deputados federais. Inclusive delitos violentos, não “característicos" das camadas dominantes, tem a possibilidade de causar esse efeito ${ }^{270}$ quando por eles praticados.

\footnotetext{
267 ZAFFARONI, Eugenio Raúl; BATISTA, Nilo; ALAGIA, Alejandro; SLOKAR, Alejandro. Direito Penal Brasileiro: primeiro volume - Teoria do Direito Penal. pp. 92-96.

${ }^{268}$ Lei do Crime Organizado.

${ }^{269}$ KARAM, Maria Lúcia. Expansão do poder punitivo e violação de direitos fundamentais. p. 3.

270 Pimenta Neves é condenado à prisão depois de uma década. Disponível em <http://maisvoce.globo.com/MaisVoce/0,MUL1662978-10345,00.html>. Acesso em 29 de maio de 2011.
} 
Nesse afã punitivo que não condiz com as experiências de suas lideranças, a "esquerda punitiva" acaba por realizar distinções até mesmo entre oprimidos ${ }^{271}$. Se, no passado, ao menos compreendia-se a situação daqueles que recorrem ao tráfico de drogas para, no dizer do Juarez Cirino, "compensar a falta de meios legítimos de sobrevivência"272, hoje permitimos, como já mencionado, que o Exército ingresse em comunidades carentes para também compensar, mas a incúria das políticas de segurança pública, além de demitirmos ${ }^{273}$ secretários que queiram discutir a descriminalização de certas drogas. Enquanto atrasamos extradições ${ }^{274}$ que interessam a países que seguem uma linha de direita, extraditamos em tempo recorde ${ }^{275}$ pessoas que tentam uma vida melhor longe de militarizados - porém aliados - países caribenhos. Cada vez mais a palavra "reacionário", que, etimologicamente, significa contra-revolucionário, pessoa de extrema-direita, mas é vulgarmente utilizada como alcunha àqueles que defendem o expansionismo penal, perde a sua razão de ser.

A impressão de que o fenômeno do Direito Penal simbólico está, no Brasil, intimamente relacionado ao recente renascer do punitivismo, não é equivocada. Os exemplos acima expostos demonstram bem como a esquerda abraçara os louros eleitorais que podem advir dos discursos de "ley y orden", antes monopolizados pela direita ${ }^{276}$, além de ter aprendido quão "benéfico" é fornecer à legislação penal e à pena funções latentes, dissimuladas nas utilitárias. Reiteramos novamente: não se trata "apenas"

\footnotetext{
${ }^{271}$ KARAM, Maria Lúcia. Expansão do poder punitivo e violação de direitos fundamentais. p. 5. ${ }^{272}$ SANTOS, Juarez Cirino dos. A Criminologia Radical. p. 29.

273 Secretário Nacional de Justiça é Exonerado. Disponível em <http://enfoquecultural.blogspot.com/2011/01/secretario-nacional-de-justica-e.html>. Acesso em 29 de maio de 2011.

${ }^{274}$ STF publica decisão de extraditar Cesare Battisti e palavra final cabe a Lula. Disponível em < http://noticias.r7.com/brasil/noticias/stf-publica-decisao-de-extraditar-cesare-battisti-e-palavrafinal-cabe-a-lula-20100416.html>. Acesso em 20 de maio de 2011.

275 Atletas cubanos queriam ir embora do país, afirma Ministro da Justiça. Disponível em <http://agenciabrasil.ebc.com.br/noticia/2007-08-08/atletas-cubanos-queriam-ir-embora-do-paisafirma-ministro-da-justica>. Acesso em 20 de maio de 2011.

${ }^{276}$ MELIÁ, Manoel Cancio; JAKOBS, Günther. Derecho Penal del Enemigo. p. 72.
} 
de punir mais, melhor ou prevenir a criminalidade, mas sim de ladear o meio ambiente político, a diplomacia externa e a governabilidade em geral. 


\section{Conclusão}

No presente trabalho, detivemo-nos em poucos aspectos desse complexo assunto que é a concessão de legitimidade às manifestações do Estado no âmbito do Direito Penal. Ao direcionarmos o foco à programação normativa manifesta e à prática penal latente, pretendíamos fazer uma breve contextualização dos contrastantes paradigmas de legitimidade, pela primeira construído, e de legitimação, pela segunda despido, para, assim, lançar uma luz tênue sobre a atual realidade relegitimadora do expansionismo penal.

Realizamos, primeiramente, uma análise meramente jurídica do princípio da exclusiva proteção de bens jurídicos enquanto principal objetivo do Direito Penal, o qual, pautado por outros princípios como fragmentariedade e subsidiariedade, dentre tantos outros, seria destinado à constituir uma limitação constitucional ao exercício do ius puniendi por seu detentor, o Estado. Constrói-se, ainda, através da teoria jurídica da pena, uma compreensão de legitimidade da sua utilização na consecução daquele objetivo-mor, pautando-a pelos fins utilitários da prevenção especial, prevenção geral, e confiando a ela as esperanças de que diminua a ocorrência de delitos.

Após, em estudo da doutrina da criminologia crítica, verificamos que a questão não é tão simples quanto nos faz crer o tecnicismo jurídico. As relações entre indivíduos e grupos que compõe determinada sociedade se resolvem de modo a configurar uma estrutura em que grupos estão próximos ou à margem do poder, sendo apenas natural que aquelas dominadoras exerçam, através de determinados instrumentos difusos, como a mídia, e institucionalizados, como o Direito Penal, estratégias de controle social destinadas a evitar mudanças. Ao verificarmos a formação do Estado moderno, percebemos como o estabelecimento do monopólio legítimo da pena causara a institucionalização do Direito Penal, enquanto instrumento 
de controle social, bem como o Estado, supostamente neutro, exercerá tal múnus voltado para a manutenção do status quo vigente.

Coube à crítica criminológica da pena a compreensão das reais funções desempenhadas pela pena nesse contexto de estagnação social. Não obstante estar dividida em duas vertentes, uma materialista e dialética, voltada para parâmetros de análise marxistas, e outra negativa e agnóstica, voltada para uma abordagem que independe das características do liberalismo econômico, a conclusão a que chegam é racionalmente idônea, dadas as respectivas particularidades. Com base no seu núcleo análogo, podemos afirmar que, enquanto a proteção de bens jurídicos atribuída ao Direito Penal revelar-se como proteção seletiva de bens jurídicos, beneficiando os setores que na estrutura de poder tem a decisão de determinar os caminhos da tipificação, a pretensão utilitária de que a pena constitua efetivo controle e redução da criminalidade deverá ser destituída de legitimidade. Essa desconstrução da legitimidade exercida pela teoria jurídica da pena a caracteriza, de fato, como ferramenta de criação de legitimação; as funções da pena, a seu turno, nada mais seriam que o conveniente espelho distorcido do fracasso dos fins utilitários.

Desse conflito entre construção e desconstrução da legitimidade, diagnosticamos a ambiguidade da política penal brasileira nos últimos vinte anos. Se, por um lado, vimos algumas demonstrações de descrença nos fins utilitários da pena, por outro, presenciamos diversas outras mais de reforço do seu exercício, na esperança de que atendessem aos anseios da comunidade por uma suposta segurança e pela igualdade do sistema criminal. Estamos em processo de satisfação da demanda relegitimadora da pena, fundado em dois fenômenos essencialmente distintos, porém, eventualmente indissociáveis.

O primeiro fenômeno é o Direito Penal simbólico, no qual identificamos um contraste entre fins e funções da pena em determinada 
legislação tipificadora ou, de forma paralela ao simbolismo que seria inerente a todo o Direito Penal, caso aceitemos as conclusões da criminologia crítica no que diz respeito à dissensão entre programação legislativa e prática. Neste momento relevante que se faça uma distinção clara e de cunho opinativo: praticamente tudo na vida tem um "quê" de simbólico, termo aqui compreendido como representação. Do estilo de vida conturbado das pseudo-estrelas do século XXI às restrições imposta aos religiosos, passando pela ânsia consumista que impera, são todas formas de se representar algo - no caso, fama, vínculo com a "suma potestade" e, é claro, dinheiro; não poderia ser diferente com o Direito. Apenas natural, deste modo, que o Direito Penal enquanto ramo possua a mesma característica de simbologia, a qual se manifesta, em especial, através dos fins utilitários.

Existirá um problema, no entanto, quando "simbólico" for somente o que houver no Direito Penal ou em suas legislações, quando os fins utilitários legitimadores de que se utiliza para buscar outras funções dissimuladas ultrapassem, por assim dizer, o objetivo maior de proteção de bens jurídicos. Por mais que partilhemos das mesmas conclusões da criminologia crítica, que há uma contraposição entre programação legislativa e prática penal e que os fins utilitários se prestam a representar ao dominado uma vida de aceitação do controle social, entendemos que classificar todo o Direito Penal como simbólico só é relevante no plano teórico. Na prática, de muito maior importância a apreciação das crias desse simbolismo inicial, constantemente apresentadas na forma de campanhas de "ley y orden", de legislações penais que visam apenas acalmar a população alarmada pela mídia, de tipificações e atos jurídico-penais com cunho essencialmente político, realizados com o fito agradar a alguns ou desagradar a outros, mas sempre em desrespeito dos parâmetros constitucionais da teoria do bem jurídico. 
O segundo fenômeno, examinado com profundo e sincero pesar, é caracterizado por um movimento de incremento do punitivismo na chamada "esquerda punitiva", que, em adição às sempre presentes tendências criminalizadoras da direita, vem a consolidar a compreensão de que o Direito Penal e a pena se presta a funções que não condizem com o que se espera dele. Empiricamente provado que a criminalização e aplicação da lei penal incidem majoritariamente sobre camadas marginalizadas do poder como forma de controle social, funda-se ela na busca da isonomia material que deveria definir o nosso Estado Democrático de Direito e pela qual tanto lutara nos últimos séculos. Para tanto, porém, desiste de levar o patamar de repressão mínima das classes dominantes para as dominadas, contentandose na igualdade de ver aplicada a todos o mal que constitui a pena. Não seria inteiramente errôneo, aliás, classificarmos todo o movimento de “esquerda punitiva” como espécie do gênero Direito Penal simbólico.

Determinados setores políticos de esquerda, parece-nos, não satisfeitos em saber e concordar com falsificação empírica dos resultados obtidos pelo utilitarismo, curiosamente creem nele como instrumento de modificação positiva e efetivação do Estado Democrático de Direito. A hipocrisia que perpassa tal compreensão da coação formal mais potente com que conta a sociedade a torna até de difícil exposição. Como consequência deste movimento cada vez mais presente, presenciamos diversos casos em que se elege um dominante para ser crucificado publicamente como caricatura de tudo que há de mal e vil na sociedade, demonizado como o "outro", como o inimigo da diminuição das desigualdades que, tenha ou não tido suas garantias constitucionais sucessivamente desrespeitadas, deve ser punido única e exclusivamente por ter melhores condições financeiras. Afinal, ninguém enriquece licitamente no Brasil, não? 
Ao apaixonadamente criticarmos os anseios punitivos dessa esquerda que desrespeita a sua história de perseguições, lutas e torturas, nos esquivamos de maquiar a situação de desigualdade jurídico-penal brasileira. Não temos porque e não escondemos quem constitui a querida clientela da política penal brasileira, somente nos recusamos a crer que o desrespeito aos pressupostos constitucionais e Direitos Humanos de um possa, de maneira verdadeiramente legítima, ser aproveitado a outrem. Inclusive expusemos que, no final das contas, essa prática de "dois pesos duas medidas" acaba se voltando contra os próprios oprimidos, ao passo que a "esquerda punitiva" aprende a lição lhe ensinada pela direita e se rende à instrumentalização característica do Direito Penal simbólico do qual é espécie, em que os fins utilitários só são úteis às escusas funções políticas.

Assim, em um exemplo ainda não mencionado, nós, militantes da advocacia penal, constantemente somos compelidos a discutir com a demanda social relegitimadora a questão da redução dos recursos aptos à defesa técnica, os quais, como é notório, dependem principalmente da condição financeira do réu. Seria uma mudança destinada a potencializar o ius puniendi quando em face de classes dominantes, mas que, paradoxalmente, traria mais prejuízos aos poucos dominados eventualmente tenham seu Direito à ampla defesa cerceado por tal medida, enquanto o cerne da aplicação penal desigual continuaria imutável. A conclusão lógica é que o pensamento direcionado à punição exacerbada dos opressores não só eventualmente se volta para os oprimidos, como também legitima e perpetua a desigualdade que pretende extirpar.

Enfim, não pretendemos aqui apenas desenhar a nossa sociedade (e o seu Direito Penal) como exemplar irreversível da perversidade inata à psique humana, por mais que a realidade simbólica e punitiva a que somos submetidos indique isso. Queremos, sim, que a sociedade desnude o manto de imparcialidade que formalmente permeia os discursos jurídico- 
midiáticos. Queremos erradicar a cultura que nos obriga a ver o eventual criminoso como causador da falência da nossa já falida sociedade, seja ele fazendeiro ou sem-terra, banqueiro ou traficante, governador ou estelionatário. Queremos atentar para os perigos que advém desse movimento relegitimador que, à direita e à esquerda, considera a pena apta a flanquear os mais diversos e escusos objetivos, da demagogia populista à política interna, passando pela externa, arrecadação fiscal, minoração das desigualdades sociais e crises diversas.

Com tais ideais em mente, só nos resta fazer referência aos inigualáveis votos de um tempo melhor, da parte da também inigualável Maria Lúcia Karam:

"Já é hora de romper com os enganosos discursos legitimadores do sistema penal e construir - ou reconstruir - pensamentos e práticas libertários e igualitários, fundados na generosidade, na fraternidade, na honestidade, na tolerância e no desapego verdadeiramente revolucionários. Respeitar e assegurar, em quaisquer circunstâncias, os direitos e garantias fundamentais expressos nas declarações universais de direitos e nas Constituições democráticas. Repudiar todas as formas de totalitarismo. Repudiar proibições, controles, vigilâncias, punições e buscar sempre a liberdade. Perceber que situações, fatos ou condutas negativos, indesejados ou danosos não desaparecem por conta do rigor penal. Perceber que somar ao dano do crime a dor da pena é multiplicar danos. Romper com essa própria idéia de crime, compreendendo a natureza política e a artificialidade de sua definição. Romper com os sentimentos de medo, de vingança e de culpa, que sustentam o clima emocional do sistema penal. Romper com o maniqueísmo que, dividindo as pessoas entre boas e más, impulsiona o desejo da punição e a busca de bodes expiatórios, de culpados individualizados e demonizados. Romper com a monopolizadora, enganosamente satisfatória e violenta reação punitiva. Buscar o fim da desigualdade e da exclusão. Buscar alimentação saudável, habitação confortável, educação de boa qualidade, lazer, cultura, dignidade, bem-estar para todas as pessoas. Deixar os medos, as inseguranças e o egoísmo de lado e buscar o convívio, a solidariedade, a compreensão, a compaixão. Deixar de lado os pragmatismos imediatistas e reacender os ideais transformadores. Com imaginação e muito debate, iremos encontrando os meios compatíveis com os fins. O primeiro passo é estabelecer os compromissos e deles não se afastar. O segundo passo é não hesitar em desejar o que pode parecer impossível"277.

${ }^{277}$ KARAM, Maria Lúcia. Expansão do poder punitivo e violação de direitos fundamentais. pp. 910. 


\section{Referências Bibliográficas}

ALVES, Cléber. Acesso à Justiça, Estado de Direito e Consolidação Democrática na América Latina: o Papel da Defensoria Pública. In: ALVES, Cléber. Acesso à justiça em preto e branco: retratos institucionais da defensoria publica. Rio de Janeiro: Lumen Juris, 2004.

ANCEl, Marc. A Nova Defesa Social: Um Movimento de Política Criminal Humanista. Tradução por Osvaldo Melo. Rio de Janeiro: Forense, 1979.

ANDRADE, Vera Regina Pereira. A Ilusão de Segurança Jurídica: Do controle da violência à violência do controle penal. $2^{\mathrm{a}}$ ed. Porto Alegre: Livraria do Advogado, 2003.

ANJOS, Fernando Vernice dos. Direito Penal Simbólico e Lei de Combate à Violência Doméstica e Familiar Contra a Mulher. Disponível em <www.ibccrim.com.br>. Acesso em 15 de maio de 2011.

ARENDT, Hannah. Da Violência. Tradução por Maria Drummond. Disponível em <www.4shared.com>. Acesso em 13 de maio de 2011.

ARISTÓTELES. Política: Livro I. Disponível em <www.4shared.com>. Acesso em 15 de maio de 2011.

Atirador invade escola e mata alunos no Rio; saiba como foi. Disponível em http://www1.folha.uol.com.br/cotidiano/899801-atirador-invade-escola-emata-alunos-no-rio-saiba-como-foi.shtml>. Acesso em 20 de maio de 2011.

Atletas cubanos queriam ir embora do país, afirma Ministro da Justiça. Disponível em <http://agenciabrasil.ebc.com.br/noticia/2007-08-08/atletascubanos-queriam-ir-embora-do-pais-afirma-ministro-da-justica>. Acesso em 20 de maio de 2011.

BALESTRA, Carlos Fontán. Tratado de Derecho Penal: Tomo I. $2^{\mathrm{a}}$ ed. Buenos Aires: Abeledo-Perrot, 1953.

BARATTA, Alessandro. Criminología Crítica y Crítica del Derecho Penal: Introducción a la sociologia jurídico-penal. Tradução para o Espanhol de Álvaro Búster. Buenos Aires: Siglo Veintiuno, 2004.

- In: BARATTA, Alessandro (Compilação in memoriam). Criminología y Sistema Penal. Buenos Aires: Editorial B. de F., 2004. 
BITENCOURT, Cezar Roberto. Manual de Direito Penal: Parte Geral. $6^{\mathrm{a}}$ ed. São Paulo: Saraiva, 2000.

BITTAR, Eduardo C. B. O Direito na Pós-Modernidade. Rio de Janeiro: Forense Universitária, 2005.

BUNDESVERFASSUNGSGERICHT, Decisão 39, 1, 57. In: ROXIN, Claus. Derecho Penal: Parte General.

BUNDESVERFASSUNGSGERICHT, Decisão 45, 187, 253. In: ROXIN, Claus. Derecho Penal: Parte General.

CASTRO, Lola Aniyar. Criminologia da Libertação. Tradução de Sylvia Moretzsohn. Rio de Janeiro: Revan, 2005.

CONDE, Francisco Muñoz. Introducción al Derecho Penal. Barcelona: Bosch, 1975.

DALLARI, Dalmo de Abreu. Elementos de Teoria Geral do Estado. $25^{\mathrm{a}}$ ed. São Paulo: Saraiva, 2006.

DE SANCTIS, Fausto Martin. Fins da pena criminal: repressão ou prevenção?. Disponível em <www.ibccrim.com.br>. Acesso em 10 de abril de 2011.

Dicionário Enciclopédico Koogan-Larousse: Volume I. Rio de Janeiro: Larousse do Brasil, 1978.

HOBBES, Thomas. Leviatã. São Paulo: Martins Fontes, 2003.

HULSMAN, Louk. Temas e conceitos numa abordagem abolicionista da justiça criminal. Tradução de Maria de Carvalho. In: PASSETI, Edson (Org.). Conversações Abolicionistas: Uma Crítica do Sistema Penal e da Sociedade Punitiva. São Paulo: IBCCRIM, 1997.

FERRAJOLI, Luigi. Direito e Razão: Teoria do Garantismo Penal. Tradução por Ana Paula Zomer Sica, Fauzi Hassan Choukr, Juarez Tavares e Luiz Flávio Gomes. $2^{a}$ ed. São Paulo: Revista dos Tribunais, 2006.

FOUCAULT, Michel. Vigiar e Punir. Tradução de Raquel Ramalhete. 32a ed. Petrópolis: Vozes, 2006.

GOMES, Luiz Flávio. Norma e Bem Jurídico no Direito Penal. São Paulo: Revista dos Tribunais, 2002. p. 54. 
HASSEMER, Winfried. Derecho Penal Simbólico y Protección de Bienes Jurídicos. Tradução para o espanhol de Elena Larrauri. In: Vários autores. Pena y Estado. Santiago: Editorial Jurídica Conosur, 1995.

IPEA analisa pobreza e miséria por regiões e estados. Disponível em $<$ http://www.ipea.gov.br/portal/index.php?option=com_content\&view=artic le\&id=1571:ipea-analisa-pobreza-e-miseria-por-regioes-eestados\&catid=4:presidencia\&Itemid=2> . Acesso em 25 de maio de 2011.

JAKOBS, Günther. Derecho Penal: Parte General. Tradução para o espanhol por Joaquin Contreras e Jose Luis Murillo. 2a ed. Madrid: Marcial Pons, 1997.

. Sobre a Teoria da Pena. Tradução de Maurício Lopes. In: LOPES, Maurício (Org.). Estudos de Direito Penal. $1^{\text {a }}$ ed. Barueri: Manole, 2003.

KARAM, Maria Lúcia. Expansão do poder punitivo e violação de direitos fundamentais. Disponível em <http://www.mundojuridico.adv.br>. Acesso em 10 de maio de 2011.

LISZT, Franz Von. Tratado de Direito Penal Alemão: Tomo I. Tradução de José Higino. Campinas: Russel, 2003.

MAIER, Julio. Derecho procesal penal: Tomo I. $2^{\mathrm{a}}$ ed. Buenos Aires: Editores del Puerto, 1999.

MATtos, Virgílio de. Esquerda Punitiva, Punição e Opção Ideológica. Disponível em < http://carlosmagalhaes.com.br/2011/04/11/esquerdapunitiva-punicao-e-opcao-ideologica/> . Acesso em 17 de abril de 2011.

MELIÁ, Manoel Cancio; JAKOBS, Günther. Derecho Penal del Enemigo. Madrid: Civitas, 2003.

MIR PUIG, Santiago. El Derecho Penal en el Estado Social y Democrático. Barcelona: Ariel, 1994.

NORONHA, Magalhães. Direito Penal: Introdução à Parte Geral. $17^{\mathrm{a}} \mathrm{ed}$. São Paulo: Saraiva, 1979.

PACHUKANIS, Evgeny Bronislavovich. Teoria Geral do Direito e Marxismo. Tradução de Silvio Donizete Chagas. São Paulo: Acadêmica, 1988. 
PARMA, Carlos. Reexaminando el Derecho Penal. Disponível em <www.4shared.com>. Acesso em 15 de maio de 2011.

PASSETTI, Edson. A atualidade do Direito Penal. In: PASSETTI, Edson (Org.). Curso Livre de Abolicionismo Penal. Rio de Janeiro: Revan, 2004.

Pimenta Neves é condenado à prisão depois de uma década. Disponível em <http://maisvoce.globo.com/MaisVoce/0,,MUL1662978-10345,00.html>. Acesso em 29 de maio de 2011.

Polícia e Exército iniciam invasão no Complexo do Alemão. Disponível em $<$ http://www.estadao.com.br/noticias/nacional,policia-e-exercito-iniciaminvasao-no-complexo-do-alemao,646417,0.htm>. Acesso em 20 de maio de 2011.

RIPOLLÉS, José Luis Diez. El Derecho Penal Simbólico y los Efectos de la Pena. Disponível em <www.4shared.com>. Acesso em 10 de abril de 2011.

ROXIN, Claus. Derecho Penal: Parte General. Tradução para o Espanhol de Diego Pena. Madrid: Civitas, 1997.

- Sentido e Limites da Pena Estatal. Tradução de Ana Natscheradactz e Maria Fernanda Palma. In: BRITO, José (Org.). Problemas Fundamentais de Direito Penal. $3^{\text {a }}$ ed. Lisboa: Vega, 1998.

SALIBA, Marcelo Gonçalves. Justiça Restaurativa e Paradigma Punitivo. Curitiba: Juruá, 2009.

SANTOS, Juarez Cirino dos. A Criminologia Radical. Rio de Janeiro: Forense, 1981.

2010

Direito Penal: Parte Geral. 4a ed. São José: Conceito Editorial,

Secretário Nacional de Justiça é Exonerado. Disponível em $<$ http://enfoquecultural.blogspot.com/2011/01/secretario-nacional-dejustica-e.html>. Acesso em 29 de maio de 2011.

SILVA, José Afonso da. Curso de Direito Constitucional Positivo. $29^{\mathrm{a}}$ ed. São Paulo: Malheiros, 2007.

SOARES, Orlando. Causas da Criminalidade e Fatores Criminológicos. Rio de Janeiro: Científica, 1978. 
SOLER, Sebastian. Derecho Penal Argentino: Tomo I. Buenos Aires: Tipográfica Argentina, 1956.

STF publica decisão de extraditar Cesare Battisti e palavra final cabe a Lula. Disponível em < http://noticias.r7.com/brasil/noticias/stf-publicadecisao-de-extraditar-cesare-battisti-e-palavra-final-cabe-a-lula20100416.html>. Acesso em 20 de maio de 2011.

STF, HC 70362-RJ, $1^{\text {a }}$ T., Rel. Ministro Sepúlveda Pertence. DJ 12.04.96.

STF, RHC 89624-RS, $1^{\text {a }}$ T., Rel. Ministra Carmen Lúcia. DJ 07.12.06.

STF, RE 552545-MG, $2^{\mathrm{a}}$ T., Rel. Ministra Ellen Gracie. DJ 20.11.08.

SULOCKI, Victoria-Amália de. Segurança Pública e Democracia: Aspectos Constitucionais das Políticas Públicas de Segurança. Rio de Janeiro: Lumen Juris, 2007.

Taxa de desemprego é a menor para abril desde 2002. Disponível em $<$ http://globonews.globo.com/videos/v/taxa-de-desemprego-e-a-menorpara-abril-desde-2002/1519204/> . Acesso em 30 de maio de 2011.

WACQUANT, Löic. As prisões da miséria. Rio de Janeiro: Jorge Zahar, 2001.

WELZEL, Hans. Direito Penal. Tradução de Afonso Celso Rezende. Campinas: Romana, 2003.

ZAFFARONI, Eugenio Raúl. La Creciente Legislación Penal y los Discursos de Emergencia. In: Vários Autores. Teorías Actuales en el Derecho Penal. Buenos Aires: Editorial Ad-Hoc, 1998.

Manual de Direito Penal Brasileiro. $2^{\text {a }}$ ed. São Paulo: Revista dos Tribunais, 1999.

ZAFFARONI, Eugenio Raúl; BATISTA, Nilo; ALAGIA, Alejandro; SLOKAR, Alejandro. Direito Penal Brasileiro: primeiro volume - Teoria do Direito Penal. $2^{\mathrm{a}}$ ed. Rio de Janeiro: Revan, 2003. 